\title{
Transforming Traditional Classrooms into Student-Centered 21 st Century Classrooms: A Developmental Process for Professional Development
}

\author{
Monica McCartney
}

Follow this and additional works at: https://researchrepository.wvu.edu/etd

\author{
Recommended Citation \\ McCartney, Monica, "Transforming Traditional Classrooms into Student-Centered 21 st Century \\ Classrooms: A Developmental Process for Professional Development" (2014). Graduate Theses, \\ Dissertations, and Problem Reports. 6190. \\ https://researchrepository.wvu.edu/etd/6190
}

This Dissertation is protected by copyright and/or related rights. It has been brought to you by the The Research Repository @ WVU with permission from the rights-holder(s). You are free to use this Dissertation in any way that is permitted by the copyright and related rights legislation that applies to your use. For other uses you must obtain permission from the rights-holder(s) directly, unless additional rights are indicated by a Creative Commons license in the record and/ or on the work itself. This Dissertation has been accepted for inclusion in WVU Graduate Theses, Dissertations, and Problem Reports collection by an authorized administrator of The Research Repository @ WVU. For more information, please contact researchrepository@mail.wvu.edu. 
Transforming Traditional Classrooms into Student-Centered $21^{\text {st }}$ Century Classrooms: A Developmental Process for Professional Development

\author{
Monica McCartney
}

Dissertation submitted to the College of Education and Human Services

at West Virginia University

in partial fulfillment of the requirements for the degree of

Doctor of Education

in

Instructional Design and Technology

Terence C. Ahern, Ph.D., Chair

Neal Shambaugh, Ph.D.

Ugur Kale, Ph.D.

Jessica Troilo, Ph.D.

Angela Dowling, Ed.D.

Department of Learning Sciences and Human Development

Morgantown, West Virginia

2014

(C) Monica McCartney, 2014 


\begin{abstract}
Transforming Traditional Classrooms into Student-Centered $21^{\text {st }}$ Century Classrooms: A Developmental Process for Professional Development

\section{Monica McCartney}

This design-based action research study utilized a model of design, implementation, and evaluation across four school semesters to improve the professional development provided to teachers in a new one-to-one computing environment. Data sources collected across all semesters helped guide changes to the design and implementation phases of the professional development. This study had one guiding research question: What are the appropriate professional development sessions and process for designing professional development in order to meet the needs of teachers as they to transform traditional classrooms into student-centered $21^{\text {st }}$ century classrooms?
\end{abstract}

Keywords: Design-based research, Developmental Research, Instructional Design, One-to-one, 1:1, Professional Development, $21^{\text {st }}$ Century Classrooms, student-centered 


\section{Biographical Sketch}

Monica McCartney is currently a Technology Integration Specialist and Academic Coach in Morgantown, West Virginia. Monica has lived 36 of her 38 years in Morgantown, leaving briefly to teach outside of the state. Monica graduated with a Bachelor of Science in Elementary Education, specializing in General Science 5-9, from West Virginia University in 1998. She began her teaching career teaching eighth grade science in Charlotte, North Carolina for two years, before returning to Morgantown. In Morgantown, Monica taught sixth grade Mathematics and English. In May 2004, she graduated with a Masters of Arts in Secondary Education, specializing in middle school mathematics. In 2010, she transferred to her current position as a Technology Integration Specialist. Monica can be reached at mlmccart@k12.wv.us. 
Running head: TRANSFORMING TRADITIONAL CLASSROOMS INTO STUDENT- iii CENTERED $21^{\text {ST }}$ CENTURY CLASSROOMS

\section{Dedication}

This study is dedicated to all of the school staff who had the vision to transform classrooms into $21^{\text {st }}$ century learning environments: the teachers, school administrators, and county-level technology staff. Thank you for all of your insight, hard-work, and dedication. Thanks also to my family for all of their support throughout this endeavor. To my parents for instilling a love of learning and my husband for your support as I locked myself in a room to write, I could not have done it without you. 


\section{Acknowledgements}

This action research study could not have been completed without the assistance of the teachers and administrators. Their ability to rally together as a team to both write such a successful grant and implement it is inspirational. Whereas my position in the building is to be there to support them, they have been my support system throughout this process. A special thanks to those who took the first steps in this endeavor: Tracy Chico, Sarah Corder, Abigail Custer, Traci DeWall, Angela Dowling, Chris Maloney, Jim Napolillo, and Cynthia SweitzerPinn. Additional thanks are extended to PJ Bell and Matt Pitek for their support both technically and mentally throughout the process.

I would also like to recognize Chris Urban and Nancy Napolillo, both of whom had the vision of implementing this school-wide initiative. Without their support, this study would never have begun.

Many thanks also to Dr. Neal Shambaugh and Dr. Terence Ahern for assisting with the organization of my research. Thank you in particular to Dr. Shambaugh for convincing me that I can let go of numbers and statistics and undertake a qualitative study. 


\section{TABLE OF CONTENTS}

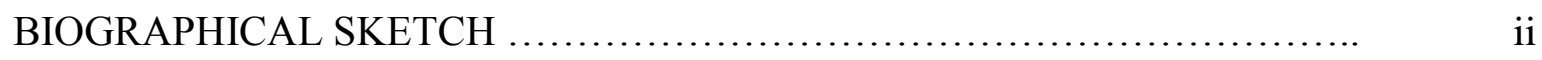

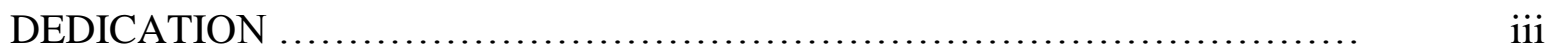

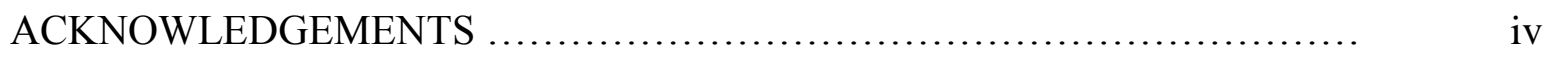

LIST OF FIGURES .................................................. viii

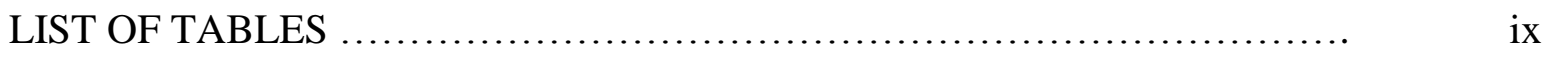

CHAPTER

Background

Need for the Study and Rationale

Significance

Intervention

Research Question

Summary of the Introduction

Glossary of Terminology

II

LITERATURE REVIEW

$21^{\text {st }}$ Century Skills

Technology Initiatives' Impact on Teaching Methodology

Teacher Beliefs

Effective Professional Development

Technology Training

Summary of Literature 
Setting

Participants

Instructional Design

Data Sources and Instruments

Data Collection Timeline

Limitations

Summary of Methodology

IV

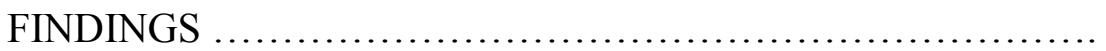

2010-2011 Semester 1

Design

Implementation

Evaluation

2010-2011 Semester 2

Design

Implementation

Evaluation

2011-2012 Semester 1

Design

Implementation

Evaluation

2011-2012 Semester 2

Design

Implementation 
Running head: TRANSFORMING TRADITIONAL CLASSROOMS INTO STUDENT- vii CENTERED $21^{\text {ST }}$ CENTURY CLASSROOMS

\section{Evaluation}

V

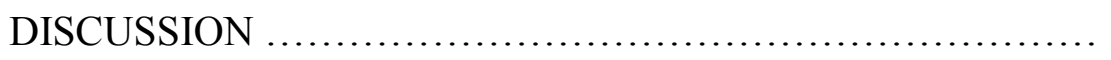

Professional Development for Transforming Classrooms

Design-Based Action Research

Limitations

Implications

Discussion Summary

REFERENCES

Appendix A: Data Sources

Appendix B: Sample from Teacher Surveys

Appendix C: Sample from Staff Interviews

Appendix D: Sample from Classroom Observations

Appendix E: Sample from Discussion Groups

Appendix F: Sample from Collected Artifacts 
Running head: TRANSFORMING TRADITIONAL CLASSROOMS INTO STUDENT- viii CENTERED $21^{\text {ST }}$ CENTURY CLASSROOMS

\section{LIST OF FIGURES}

Figure 1 Instructional design model utilized in study .......................... 17 
Running head: TRANSFORMING TRADITIONAL CLASSROOMS INTO STUDENT- $\quad$ ix CENTERED $21^{\text {ST }}$ CENTURY CLASSROOMS

\section{LIST OF TABLES}

Table 1 Data Sources for the Developmental Research Cycle for Each Semester ..... 19

Table 2 WVDE EETT 1:1 Computing Implementation Timeline ................... 20

Table 3 Frequency of Professional Development Sessions by Teaching Teams ....... 21

Table 4 Data Collection Sources .......................................... 25

Table 5 Timeline of Data Collection ........................................ 26

Table 6 Study Limitations and Strategies to Circumvent ......................... 28

Table 7 Recurring Themes for Each Data Source during 2010-2011 Semester 1 ...... 35

Table 8 Recurring Themes for Each Data Source during 2010-2011 Semester 2 ..... 41

Table 9 Recurring Themes for Each Data Source during 2011-2012 Semester 1 ..... 46

Table 10 Recurring Themes for Each Data Source during 2011-2012 Semester 2 _.... 51

Table 11 Common Themes from Pre-and Post-surveys ......................... 52

Table 12 Common Themes from Teacher Interviews ............................ 53

Table 13 Common Themes from Learner Management System ..................... 54 


\section{Chapter I - Introduction}

\section{Background}

The host middle school was a recent recipient of the West Virginia Department of Education's Enhancing Education through Technology (EETT) grant. The objective of the grant was to create a one-to-one computing educational environment over the course of a two year period. At the end of the two year period, a laptop was available for each student attending the middle school. While the staff of educators at the school showed overwhelming support for the initiative during the application process, professional development was needed in order to transform the school into student-centered $21^{\text {st }}$ century classrooms.

\section{Need for the Study and Rationale}

Today’s businesses are looking for employees who can multi-task, make decisions independently, work collaboratively, and adapt as necessary. Technological changes have made these skills necessary both in and out of the workplace. Additionally, advanced communications have created a global workplace with business associates all over the world. It is no longer enough to be knowledgeable in content areas; employees and citizens need to have the ability to adapt, troubleshoot, cooperate, and seek out new solutions. For these reasons, it has become vital to provide students with the skills necessary to thrive in these environments (Partnership for $21^{\text {st }}$ Century Skills, 2003).

As American businesses alter their expectations of employees, the school systems charged with shaping the future employees must also change. Educators have begun to transition their traditional teaching methods to meet the needs of their current students in the workplaces of the future. For many educators, this change has meant a greater emphasis on incorporating digital technology. 


\section{Significance}

In response to the call for better preparation of our students in the workplace, many schools, school-districts, and, in some cases, entire states have begun transitioning classrooms to one-to-one computing environments. Providing digital technology for every student in a classroom is not enough. Educating teachers and students on how to use the tools inherent to the technology is not enough. Teachers must integrate the technology seamlessly into their existing curriculum in order to make the technology an effective and real-world tool. In order for a oneto-one technology initiative to be successful, teachers must be provided with professional development to assist them with adequately integrating technology into their existing curricula.

\section{Intervention}

This study utilized a design-based action research approach to shape professional development in a one-to-one computing environment. A cycle of developmental research was performed across four school semesters. Core content teachers were granted laptop computers for their classrooms in a phased-in approach throughout the four semesters. Despite this method of laptop distribution, all teachers were provided the same professional development across all four semesters.

\section{Research Question}

Developmental Research Question: What are the appropriate professional development sessions and process for designing professional development in order to meet the needs of teachers as they to transform traditional classrooms into student-centered $21^{\text {st }}$ century classrooms? 
CENTERED $21^{\text {ST }}$ CENTURY CLASSROOMS

\section{Summary of the Introduction}

Like many schools throughout the United States, the school in this study had been granted the opportunity to transform itself into a one-to-one computing school. The impetus for such a transition was the need for greater student preparation for the future workforce. Providing the equipment was not enough to ensure that real-world skills necessary were imparted to the students in the classrooms. Teacher-learning through professional development was necessary to guarantee that the technology was used effectively. This design-based action research study looks at how such professional development was selected and delivered.

\section{Glossary of Terminology}

One-to-one (1:1) Computing: For the purposes of this study, one-to-one computing is defined as one laptop computer available for every student in a given classroom. While teaching methods may vary the exact ratio of students per laptop for each task, in this one-to-one scenario a laptop was available for each student.

Technology Integration Specialist (TIS): The West Virginia Department of Education grants the advanced credential of TIS to educators who have successfully completed 320 hours of WVDE approved training. Educators employed in the role of TIS are utilized as support staff to assist and train teachers on the incorporation of technology within their curriculum.

Implementation Team: As the host school began the process of transforming to 1:1 computing environment, six teachers, administrators, the building-level TIS, and the county-level TIS formed a committee referred to as the Implementation Team. The teachers on this team were made up of two teachers from each grade level (6-8) and were the first in the building to receive laptop carts and begin the process. 
CENTERED $21^{\text {ST }}$ CENTURY CLASSROOMS

Core Content Teachers: Core content teachers are those primarily responsible for delivering instruction in mathematics, science, social studies, English, and reading. At the host school, this accounted for 16 of the 31 full-time instructors. In addition to the 16 core content teachers, 4 of the special educators were also responsible for delivering core content. Over the course of the two-year study, laptop carts were provided to these 20 teachers.

Related Arts Teachers: Related arts teachers are teachers who provide instruction in an area outside of the core content. This content includes (but is not limited to) physical education, graphic arts, musical arts, wood-working, consumer science, world languages, and computer applications. Nine of the 31 instructors at the host school were considered related arts teachers. These nine teachers did not receive a laptop cart for their classroom, but did have opportunities to schedule classes in any of the three stationary computer labs.

Learner Management System (LMS): In this study, learner management system refers to the electronic platform utilized by the school to provide online instruction and track student progress. The county provides access to Edline for such purposes. Applications of Edline include the ability to record and report grades; create and disseminate online quizzes, surveys, homework hand-in assignments, discussion boards, and blogs; post news, documents, and links; and maintain a calendar of events.

Blended Learning: Blended learning refers to the combination of online content delivery and face-to-face content delivery. Prior to this study, all of the teachers at the host school utilized the learner management system for the reporting of grades and providing resources, such as documents and links. For this reason, blended learning will be used to refer to the use of interactive assignments, quizzes, surveys, discussion boards, and blogs. 


\section{Chapter II - Literature Review}

\section{$21^{\text {st }}$ Century Skills}

In order to adequately prepare students for life in the 21 st century, the Partnership for 21st Century Skills (2003) has identified the specific knowledge and skills necessary. The essential knowledge and skills are organized into three categories, 21st century content (global awareness, financial and business literacy, and civic literacy), learning and thinking skills, and information and communications technology (ICT) literacy.

Perhaps the broadest category of 21 st century skills, learning and thinking skills, are those essential in giving learners the ability to connect new information. This broad category, sometimes referred to "knowing how to learn," covers the areas of critical thinking, problem solving, creativity, self-directional skills, collaboration, communication skills, and information and media literacy. Critical thinking, problem solving, and creativity skills are designed to create learners who crave challenging tasks, look for multiple solutions, and reflect on ideas. Learners should be encouraged to take risks in order to find potential solutions rather than focusing on the “right answer" (NCREL, 2003).

The Partnership for $21^{\text {st }}$ Century Skills (2003) defines "information and communications technology literacy" as the result of combining learning and thinking skills with $21^{\text {st }}$ century technology tools. A student capable of harnessing technology tools to effectively research, problem-solve, collaborate, communicate, and create would be considered ICT literate.

With the understanding that students need to be better prepared for the future workforce, many school districts are attempting to transition towards ubiquitous technology to leverage the use of $21^{\text {st }}$ century tools and increase ICT literacy, thereby increasing student learning and thinking skills (Apple Inc., 2008). 
CENTERED $21^{\text {ST }}$ CENTURY CLASSROOMS

\section{Technology Initiatives' Impact on Teaching Methodology}

While the notion of having technology available for every student has gained popularity, it is not a new idea. As early as 1986, the Apple Classrooms of Tomorrow (ACOT) project has been studying the outcomes of students having constant access to technology. Since that time, a multitude of studies have been completed to capture student learning outcomes and changes in teaching methods in technology implementation initiatives. For the purposes of this inquiry, only studies reporting implications to teaching methodology have been analyzed.

In their compilation of laptop initiatives, Dunleavy, Dexter, and Heinecke (2007) stated that teachers in one-to-one laptop environments self-reported that the most frequent use of technology by students and teachers was online research in conjunction with productivity tools. Drill and practice was another frequent use of technology, but unlike many traditional classrooms, the drill and practice was typically individualized and learner-centered.

Learner-centered instruction is commonly reported as an outcome of one-to-one technology environments. Multiple studies report that ubiquitous technology lends itself to a more constructivist approach to classroom instruction, resulting in a student-centered environment with a teacher facilitating (Dunleavy et al., 2007; Muir-Herzig, 2004; Windschitl \& Sahl, 2002). Muir-Herzig (2004) reported that "technology brings about changes to the classroom roles and organization. It allows the students to become more self-reliant. Students may use peer coaching, and teachers may function more as facilitators than lecturers." Additionally, in his 2006 compendium of North American laptop initiatives, Fox recounted that greater than $70 \%$ of teachers in a one-to-one computing environment found that they were better capable of individualizing instruction while meeting curriculum goals with the addition of the technology. 
Dunleavy et al. (2007) summarized their findings by asserting that one-to-one technology adds value to teaching and learning in six ways: teachers' ability to formally assess learning, the ability to individualize instruction, the capacity for self-guided instruction, access to online resources, the capacity for student interaction and collaboration, and the availability of electronic communication and material management.

While several studies indicate that ubiquitous technology lends itself to student-centered learning, Widschitl and Sahl (2002) maintain that pervasive technology does not have a direct causal relationship with constructivist instruction. They argue that how teachers choose to utilize technology depends on a combination of factors rooted in their personal histories and beliefs about student learning. Opfer and Pedder (2011) agree and take the idea a step further by stating that teachers' willingness to learn new ideas and methods is dependent on the interplay between their past experiences and beliefs about student learning.

\section{Teacher Beliefs}

Teachers' beliefs regarding student learning and teaching methods directly affect the instructional decisions that they make (de Vries, Jansen, \& van de Grift, 2013). Studies have shown that while teachers' philosophies of student learning may be reformed over time (Pecore, 2013), beliefs established earlier are more difficult to change (de Vries et al., 2013). Additionally, Pecore (2013) points out that changing a teaching philosophy is "unlikely to occur due to a professional development workshop".

Despite the opinion that teachers' beliefs cannot be changed by a single workshop, Windschitl and Sahl (2002) point out that school culture can influence the thinking of the teachers working within its walls; the perceived institutional beliefs of what constitutes "good teaching" influences decisions made by individual teachers. Opfer and Pedder (2011) concur by 
stating that "the norms of the school, its structures and practices, both enable and constrain teachers". In turn, individual teacher and administrator beliefs and experiences are among the components that make up the school culture as a whole. As teachers participate in learning activities and modify their philosophies, they also stimulate the development of the school as a whole (de Vries et al., 2013).

\section{Effective Professional Development}

From the research discussed thus far, it is easy to understand why Opfer and Pedder (2011) describe teacher learning as "a complex system rather than an event". It is clear that there are many dynamics interacting to influence whether teachers will or will not alter their beliefs and practices. In an attempt to gain greater understanding on the factors that have the most significant effect on teacher learning, Desimone, Porter, Garet, Yoon, and Birman completed a three year longitudinal study on teachers' learning and found that effective professional development comprised of six features: reform type (the activity structure), duration (length of activity), collective participation (groups from the same organization), active learning (handson), coherence (aligned to goals), and content focus (emphasis on deepening content knowledge).

Many researchers agree that the duration of professional development activities is essential to ensuring that the activities are effective. Garet, Porter, Desimone, Birman, and Yoon (2001) maintain that "sustained and intensive professional development is more likely to have an impact, as reported by teachers, than is shorter professional development". Similarly, Brand (1998) indicates that "training must be ongoing and not limited to 'one-shot' sessions". Research completed by both Brand (1998) and Opfer and Pedder (2011) indicated that in order for professional development to be effective, teachers had to be given time to explore, 
understand, and practice new ideas. The amount of time needed for such exploration is different for each teacher and is dependent upon the teacher's comfort level with the new knowledge (Brand, 1998).

In addition to the length of professional development and exploration time, coherence to curriculum goals is another important factor to effective teacher learning. This is particularly important when introducing new teaching methods, such as technology integration. Tying new learning to preexisting content knowledge and routines allows teacher-learners to visualize how to integrate the new methods into the classroom (Brand, 1998). This notion was reinforced by Opfer and Pedder in their 2011 study which stated that "teachers learn most effectively when they are required to engage with materials of practice". Although this research suggests that professional development should be framed around curriculum goals, Muir-Herzig (2004) notes that technology training frequently emphasizes how to use the equipment, but often fails to impart how to integrate the equipment into the curriculum.

Collective participation is lauded by many researchers as a key component of any effective professional learning. Groups of teachers from the same school, teaching the same subject, or teaching the same grade who participate in learning activities together are more likely to increase knowledge and change classroom practices (Garet et al. 2001; Levine \& Marcus, 2010; Opfer \& Pedder, 2011). When teachers from the same school participate in the same professional development opportunities, they are more likely to share with one another to solve problems and share strategies. This creates an environment where changes in teaching strategies become a collective effort (Opfer \& Pedder, 2011). Opfer and Pedder (2011) caution, however, that much like the duration of exploration, the amount of collaboration necessary for each instructor will vary based on need. 
CENTERED $21^{\text {ST }}$ CENTURY CLASSROOMS

\section{Technology Training}

In research directly related to technology training, researchers again stressed the importance of collective participation. Several studies indicated that technology training was most effective when teachers were surrounded by others who were also experimenting with technology integration (Becker, 1994; Brand, 1998; Dwyer, 1994; Windschitl \& Sahl, 2002). Brand (1998) expands to state that learning with a peer "helps teachers overcome the insecurity and fear of applying what they have learned in workshops". Additionally, a teacher working with a peer who models good technology integration creates more confidence in integrating the technology into their own classroom. Even when collective participation was not a feature of the initial technology training, Dwyer (1994) reported that ACOT teachers began collaborating with one another to share experiences and strategize.

Collaboration and support is a vital component to professional development as school districts begin to transform traditional classrooms to 1:1 teaching environments. Teachers have self-reported that not having adequate support is among the obstacles to effectively integrating technology into their instruction (Fox, 2006). To overcome this, Muir-Herzig (2004) suggests that schools invest in a full-time school-level technology resource coordinator. Brand (1998) agrees and stresses the point by stating that creating such a position is "one of the most effective ways to align staff development with the district/school goals". He further explains the benefits by describing the potential responsibilities of this role: "ensure school/district objectives are met; take responsibility for aligning and organizing staff development; support teachers both emotionally and technically; work with a core group of teachers representing the district's subject areas and grades; coordinate time for teachers to explore and learn the new technology; 
CENTERED $21^{\text {ST }}$ CENTURY CLASSROOMS

and act as the essential link for empowering all teachers to effectively use technology and integrate it into the overall curriculum".

\section{Design-Based Research}

Educational researchers' approach to technology integration initiatives and educational research in general is changing. Many in educational researchers have begun promoting designbased research as a better approach to educational research (Collins, Joseph, \& Bielaczyc, 2004; Reeves, 2006; van den Akker, 1999). Both Reeves (2006) and van den Akker (1999) suggest that a design-based research approach, with its evolutionary nature, is better suited for reform efforts and large-scale initiatives. As van den Akker (1999) points out, reform efforts "are often multi-layered, including both large-scale policies and small-scale realizations." Design-based research can make progress in regards to both top-down initiatives and local implementation through its enhancement of both educational theory and educational practice (Collins, Joseph, \& Bielaczyc, 2004. Additionally, through this refinement of practice and theory, such research can yield instructional design models that may be utilized for organizational training (Andrews \& Goodson, 1980).

As a branch of research, design-based research suffers from a lack of agreement regarding terminology. In literature, design-based research is often referred to as design studies, design experiments, design research, development research, developmental research, formative research, formative inquiry, formative experiments, formative evaluation, and engineering research (van den Akker, 1999). No matter the name, the goal of such research is the same; design-based research aims to study the design, development, and implementation of instructional models, while solving real-world problems in real-world settings (Andrews \& Goodson, 1980; Design-Based Research Collective, 2003; Richey, Klein, \& Nelson, 2004; Wang 
\& Hannafin, 2005). Such studies are conducted utilizing iterative models of design, implementation, and evaluation (Andrews \& Goodson, 1980, Design-Based Research Collective, 2003; Richey, Klein \& Nelson, 2004; Wang \& Hannafin, 2005). Through successive cyclic or spiral iterations, the designed interventions can be refined (Collins, Joseph, \& Bielaczyc, 2004; Richey, Klein, \& Nelson, 2004; van den Akker, 1999; Wang \& Hannafin, 2005). Due to its cyclic nature, outcomes from each iteration can be evaluated and utilized to redesign the next iteration, providing focus to the implementation (Wang \& Hannafin, 2005).

As previously noted, design-based research provides an approach for solving real-world problems in real-world settings. Such studies focus on practical problems in education to inform educational practice (Brown, 1992; Reeves, 2000; Richey, Klein, \& Nelson, 2004; van den Akker, 1999). Additionally, setting such research studies in naturalistic settings, allows for immediate application of solutions that benefit all stakeholders (Barab \& Squire, 2004; Richey, Klein, \& Nelson, 2004; Reeves, 2000). As stated by Barab \& Squire (2004), "Research paradigms that simply examine processes as isolated variables within laboratory settings will lead to incomplete understanding of their relevance in more naturalistic settings." Similarly, Reeves (2000) points out that "Design research is not an activity that an individual researcher can conduct in isolation from practice."

A key component of context-specific research is the ability for the researcher to interact and collaborate with educators and other practitioners. This collaboration among researchers and practitioners is essential in identifying the problems and evaluating the efficacy of interventions (Design-Based Research Collective, 2003; Reeves, 2000; Reeves 2006; van den Akker, 1999; Wang \& Hannafin, 2005). Collaboration with practitioners also means that the research goals and outcomes will be suitable for the local need(s). Whereas the researchers' design agenda may 
initiate from a more generalized focus, collaboration in the naturalistic setting will ensure that local needs are met (Design-Based Research Collective, 2003). It is important to note, however, that due to the cyclic nature of design-based research, one study will involve multiple cycles of design, implementation, and evaluation. As such, it is imperative that all stakeholders have a commitment to continued collaboration over an extended period of time (Design-Based Research Collective, 2003).

Due to the context-specific nature of design-based research, concern over the ability to generalize findings to other settings may arise. In fact, Collins, Joseph, \& Bielaczyc (2004) point out that "the effectiveness of a design in one setting is no guarantee of its effectiveness in other settings." However it is important to reiterate that the goal of design-based research is to advance practical local applications as well as generalized learning theories (Barab \& Squire, 2004; Design-Based Research Collective, 2003; Reeves, 2000; Richey, Klein, \& Nelson, 2004). As such, van den Akker (1999) maintains that practitioners in other locales should be encouraged to attempt incorporating theoretical findings into their own context.

In addition to concern over the ability to make generalizations to a larger population, design-based research methodology may also be called into question. Unlike traditional research methods, designed-based research does not isolate variables, but instead attempts to investigate many interrelated aspects of the research simultaneously in realistic settings leading to an apparent lack of control (Collins, Joseph, \& Bielaczyz, 2004; van den Akker, 1999; van den Akker, Gravemeijer, McKenney, \& Nieveen, 2006). Brown (1992) points out this reduction in experimental control is a "trade-off" for the richness of the natural context.

Additionally, Barab \& Squire (2004) note that design-based researchers are likely to be deeply invested in all stages of the development cycle; as such, objectivity may become difficult. 
In order to increase objectivity, multiple sources should be analyzed at each stage of the development cycle (Barab \& Squire, 2004; Design-Based Research Collective, 2003; Richey,

Klein, \& Nelson, 2004; Wang \& Hannafin, 2005). Design-based research utilizes mix methods to analyze sources (Design-Based Research Collective, 2003). Specific sources and methods should be selected based upon the specific research tasks and questions (Reeves, 2000).

\section{Summary of Literature}

Despite the research showing the significance of collaboration and support in teacher learning, it is important to reiterate that professional development and teacher learning do not have a simple cause-and-effect relationship. As noted earlier, "teacher learning is a complex system" and as such there are many factors contributing to its success or failure. Opfer and Pedder (2011) note that due to this dynamic system, "there are many ways of achieving the same learning effects. The specific sets of activities, systems, and supports for learning we use in one context, with one set of teachers, may be quite different from those that would be necessary to achieve the same end in another context with a different set of teachers."

Design-based research aims to close the gap between theory and practice. Through the process of producing and refining a model of intervention in an authentic setting, researchers attempt to generate broad theories that may be generalized to new settings. While the specific activities and supports may not carry over to a new context, the process of design, implementation, and analysis of such activities may be generalized and thus, provide the support necessary for problem-solving in a new context. 


\section{Chapter III - Methodology}

\section{Setting}

This design-based action research study was conducted at a middle school housing grades six through eight located in a small urban community in West Virginia. The student population of the host school is approximately 500 students. Both the seventh and eighth grade teaching teams contain one teacher for each core content area (English, reading, mathematics, science and social studies). The sixth grade teaching team consists of six teachers, each teaching multiple content areas.

In the fall of 2010, the school received a West Virginia Department of Education (WVDE) Enhancing Education through Technology (EETT) grant providing funding for one-toone technology over the course of two school years. The grant application was written by the building's teachers, support staff, and administration, as well as county-level technology staff.

\section{Participants}

Teachers. While the developmental action research studied the transformation of the entire school, much of the research was focused on six middle school teachers. These six teachers were selected by means of purposive sampling based upon their inclusion in the school's "Implementation Team," or the teachers selected to be the first in the building to begin the one-to-one computing initiative. These six teachers, two at each grade level, were selected to begin the implementation process based on their technology literacy skills and willingness to adapt their instruction to integrate technology on a regular basis.

Technology specialists and administrators. Four specialists and/or administrators were directly involved in planning and implementing the weekly professional development sessions. 
- School Technology Integration Specialist (TIS)/Academic Coach (primary researcher for this study): The school's TIS and Academic Coach, was responsible for collaborating with the rest of the support staff and administration to provide appropriate professional development. The building-level TIS holds an authorization/credential as a Technology Integration Specialist through the West Virginia Department of Education (WVDE).

- County Technology Integration Specialist (TIS): At the time of this study, the county school system hired one TIS who was available to assist at all schools throughout the county, as well as the board offices. This county TIS held an office at the middle school being studied during the 2010-2011 school year, in order to facilitate the requirements of the WVDE EETT grant. Along with the school's TIS, other support personnel, and administrators, she was responsible for providing professional development to the school's instructors. The county TIS holds WVDE TIS credentials.

- County Technology Director: The Technology Director for the county school system was actively involved in steering the professional development and EETT grant requirements.

- Principal: The principal of the school also collaborated with the technology staff to guide the direction of the school-wide professional development.

\section{Instructional Design}

The study was a design-based action research study utilizing a systematic process (instructional design model) of design, implementation, and evaluation to shape professional development. Figure 1 illustrates the instructional design model utilized in this study. A cycle of developmental research with the data sources for each stage is visualized in Table 1. 


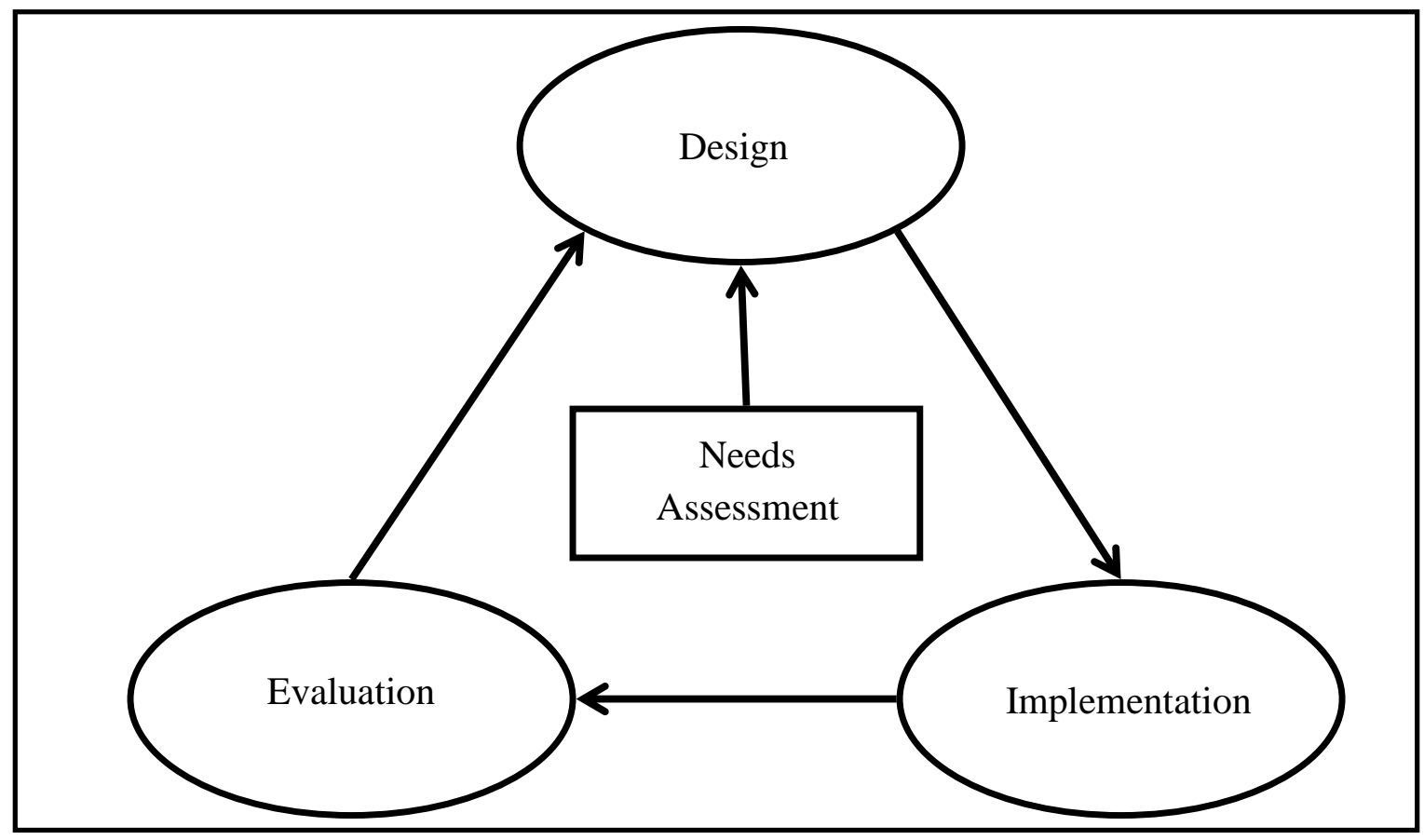

Figure 1. Instructional design model utilized in study.

Needs Assessment: The initial needs assessment, conducted in the fall of 2010, was the focus for the design structure, providing data that drove the initial design, as well as redefining the overall project goal through each iteration of the process.

Design. The initial design of professional development sessions was based upon the goals expressed within the needs assessment. Each subsequent cycle was redesigned based upon analysis of data at the evaluation stage and the overall goals of the needs assessment.

Implementation. Due to the existing structure of the WVDE EETT grant received by the school, it was necessary to implement professional development and research in phases. The grant document outlined a specific phased-in approach, in which classroom sets of laptops were to be provided to small portions of each grade level team across four semesters. A timeline of the grant dictated phases can be seen in Table 3.

Prior to 2010-2011 school year, the staff received 30 minutes of professional development on technology resources during their team planning periods once per month. This 
professional development was provided by the school's previous technology instructor and focused on introducing teachers to various online resources and understanding benchmark assessment programs.

Beginning in the fall of 2010, the school's newly hired Technology Integration Specialist provided job-embedded professional development. During the first semester of the 2010-2011 school year, professional development sessions were held for 30-45 minutes once per week for core subject teachers and 30-40 minutes every other week for the school's related arts instructors, during team planning periods. During the second semester, professional development sessions were held for 30-40 minutes every other week for all teaching staff members. Additional sessions were held throughout the year before and after school, as well as during the school's Instructional Support and Enhancement (ISE) days. Table 3 details the frequency of professional development for the school's instructors.

Evaluation. Data collected from teachers and support staff was analyzed for efficacy. Based upon the evaluation of the implementation phase, the design for professional development was revised, and the cycle continued with all teachers across four semesters. 
CENTERED $21^{\text {ST }}$ CENTURY CLASSROOMS

Table 1: Data Sources for the Developmental Research Cycle for Each Semester

\begin{tabular}{|c|c|c|c|}
\hline & Design: & Implementation: & Evaluation: \\
\hline $\begin{array}{l}2010-2011 \\
\text { Semester } 1\end{array}$ & $\begin{array}{ll}\text { Data Sources: } \\
\text { - } & \text { Teacher focus } \\
\text { groups } \\
\text { - } \text { Teacher survey } \\
\text { - } \text { Classroom } \\
\text { observations } \\
\text { - } \text { Discussion } \\
\text { groups } \\
\text { - Computer lab } \\
\text { calendars } \\
\end{array}$ & $\begin{array}{l}\text { Data Sources: } \\
\text { - } \quad \text { Teacher focus groups } \\
\text { - } \quad \text { Teacher interviews } \\
\text { - } \quad \text { Professional development training } \\
\text { materials and artifacts } \\
\text { - } \quad \text { Professional development agendas } \\
\text { - } \quad \text { Discussion groups } \\
\text { - } \quad \text { Classroom observations } \\
\text { - } \quad \text { Anecdotal records }\end{array}$ & $\begin{array}{l}\text { Data Sources: } \\
\text { - } \quad \text { Anecdotal } \\
\text { records } \\
\text { - } \quad \text { Teacher } \\
\text { created } \\
\text { artifacts } \\
\text { - } \text { Discussion } \\
\text { groups }\end{array}$ \\
\hline $\begin{array}{l}2010-2011 \\
\text { Semester } 2\end{array}$ & $\begin{array}{l}\text { Data Sources: } \\
\text { - } \quad \text { Teacher focus } \\
\text { groups } \\
\text { - } \begin{array}{l}\text { Discussion } \\
\text { groups }\end{array}\end{array}$ & $\begin{array}{l}\text { Data Sources: } \\
\text { - } \quad \text { Teacher focus groups } \\
\text { - } \quad \text { Teacher created artifacts } \\
\text { - } \quad \text { Professional development training } \\
\text { materials and artifacts } \\
\text { - Professional development agendas } \\
\text { - School-wide policies } \\
\text { - } \quad \text { Discussion groups } \\
\text { - } \quad \text { Classroom observations }\end{array}$ & $\begin{array}{l}\text { Data Sources: } \\
\text { - Teacher } \\
\text { interviews } \\
\text { - Anecdotal } \\
\text { records } \\
\text { - Teacher } \\
\text { created } \\
\text { artifacts } \\
\text { Discussion } \\
\text { groups } \\
\end{array}$ \\
\hline $\begin{array}{l}2011-2012 \\
\text { Semester } 1\end{array}$ & 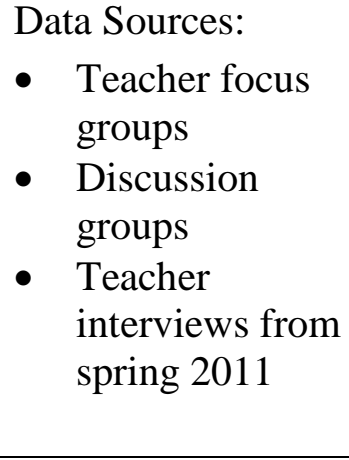 & $\begin{array}{l}\text { Data Sources: } \\
\text { - } \quad \text { Teacher focus groups } \\
\text { - } \quad \text { Teacher created artifacts } \\
\text { - } \quad \text { Professional development training } \\
\text { materials and artifacts } \\
\text { - } \quad \text { Professional development agendas } \\
\text { - } \quad \text { School-wide policies } \\
\text { - } \quad \text { Discussion groups } \\
\text { - } \quad \text { Classroom observations }\end{array}$ & $\begin{array}{l}\text { Data Sources: } \\
\text { - Anecdotal } \\
\text { records } \\
\text { - } \text { Teacher } \\
\text { created } \\
\text { artifacts } \\
\text { - } \text { Discussion } \\
\text { groups }\end{array}$ \\
\hline $\begin{array}{l}2011-2012 \\
\text { Semester } 2\end{array}$ & $\begin{array}{l}\text { Data Sources: } \\
\text { - } \quad \text { Teacher focus } \\
\text { groups } \\
\text { - Classroom } \\
\text { observations } \\
\text { - Discussion } \\
\text { groups }\end{array}$ & $\begin{array}{l}\text { Data Sources: } \\
\text { - Teacher focus groups } \\
\text { - Teacher interviews } \\
\text { - } \text { Teacher created artifacts } \\
\text { - } \text { Professional development training } \\
\text { - } \text { materials and artifacts } \\
\text { - } \text { Professional development agendas } \\
\text { - } \quad \text { Discussion groups } \\
\text { - } \quad \text { Classroom observations }\end{array}$ & $\begin{array}{l}\text { Data Sources: } \\
\text { - Anecdotal } \\
\text { records } \\
\text { - Teacher survey } \\
\text { - Teacher } \\
\text { interviews } \\
\text { - Teacher } \\
\text { created } \\
\text { artifacts } \\
\text { - Discussion } \\
\text { groups }\end{array}$ \\
\hline
\end{tabular}


CENTERED $21^{\text {ST }}$ CENTURY CLASSROOMS

Table 2: WVDE EETT 1:1 Computing Implementation Timeline

\begin{tabular}{|c|c|c|c|}
\hline \multirow{2}{*}{$\begin{array}{l}2010-2011 \\
\text { Semester } 1\end{array}$} & \multicolumn{3}{|c|}{ All teaching staff will receive a laptop for school use. } \\
\hline & \multicolumn{3}{|c|}{$\begin{array}{l}\text { All teaching staff will receive professional development for } 1: 1 \text { computing } \\
\text { and } 21^{\text {st }} \text { century classroom transformation. }\end{array}$} \\
\hline \multirow{2}{*}{$\begin{array}{c}\text { 2010-2011 } \\
\text { Semester } 2 \\
\text { (Implementation } \\
\text { Team) }\end{array}$} & $\begin{array}{l}\text { Two sixth grade } \\
\text { classrooms (both } \\
\text { science teachers) will } \\
\text { receive 1:1 computers }\end{array}$ & $\begin{array}{c}\text { Two seventh grade } \\
\text { classrooms (English and } \\
\text { science) will receive 1:1 } \\
\text { computers }\end{array}$ & $\begin{array}{l}\text { Two eighth grade } \\
\text { classrooms (English and } \\
\text { social studies) will } \\
\text { receive 1:1 computers }\end{array}$ \\
\hline & \multicolumn{3}{|c|}{$\begin{array}{l}\text { All teaching staff will receive professional development for } 1: 1 \text { computing } \\
\text { and } 21^{\text {st }} \text { century classroom transformation. }\end{array}$} \\
\hline \multirow[t]{2}{*}{$\begin{array}{l}2011-2012 \\
\text { Semester } 1\end{array}$} & $\begin{array}{c}\text { Two sixth grade } \\
\text { classrooms (both math } \\
\text { teachers) will receive } \\
\text { 1:1 computers }\end{array}$ & $\begin{array}{c}\text { Two seventh grade } \\
\text { classroom (social studies } \\
\text { and reading) will receive } \\
\text { 1:1 computers }\end{array}$ & $\begin{array}{c}\text { One eighth grade } \\
\text { classroom (math and } \\
\text { science) will receive 1:1 } \\
\text { computers }\end{array}$ \\
\hline & \multicolumn{3}{|c|}{$\begin{array}{l}\text { All teaching staff will receive professional development for } 1: 1 \text { computing } \\
\text { and } 21^{\text {st }} \text { century classroom transformation. }\end{array}$} \\
\hline \multirow[t]{2}{*}{$\begin{array}{l}2011-2012 \\
\text { Semester } 2\end{array}$} & $\begin{array}{l}\text { Two sixth grade } \\
\text { classrooms (both } \\
\text { social studies teachers) } \\
\text { will receive } 1: 1 \\
\text { computers }\end{array}$ & $\begin{array}{l}\text { One seventh grade } \\
\text { classroom (math) will } \\
\text { receive } 1: 1 \text { computers }\end{array}$ & $\begin{array}{c}\text { One eighth grade } \\
\text { classroom (reading) will } \\
\text { receive 1:1 computers }\end{array}$ \\
\hline & \multicolumn{3}{|c|}{$\begin{array}{l}\text { All teaching staff will receive professional development for } 1: 1 \text { computing } \\
\text { and } 21^{\text {st }} \text { century classroom transformation. }\end{array}$} \\
\hline
\end{tabular}




\section{CENTERED $21^{\text {ST }}$ CENTURY CLASSROOMS}

Table 3: Frequency of Professional Development Sessions by Teaching Teams

\begin{tabular}{|c|c|c|c|c|}
\hline & $\begin{array}{c}6^{\text {th }} \text { Grade Teaching } \\
\text { Team }\end{array}$ & $\begin{array}{c}7^{\text {th }} \text { Grade Teaching } \\
\text { Team }\end{array}$ & $\begin{array}{c}8^{\text {th }} \text { Grade Teaching } \\
\text { Team }\end{array}$ & $\begin{array}{c}\text { Related Arts } \\
\text { Teaching Team }\end{array}$ \\
\hline $\begin{array}{l}\text { Fall } \\
2010\end{array}$ & 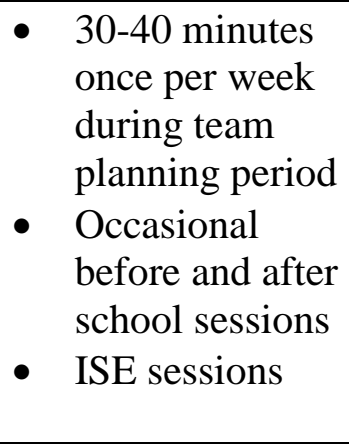 & 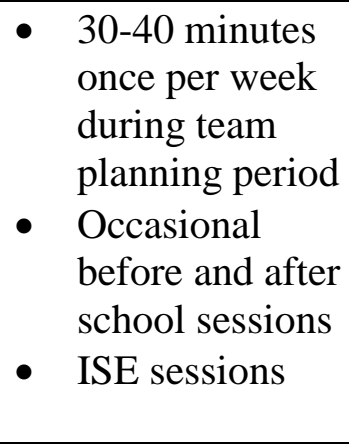 & $\begin{array}{ll}\text { - } & \text { 30-40 minutes } \\
\text { once per week } \\
\text { during team } \\
\text { planning period } \\
\text { - } & \text { Occasional } \\
\text { before and after } \\
\text { school sessions } \\
\text { - } \\
\text { ISE sessions }\end{array}$ & $\begin{array}{ll}\text { - } & \text { 30-40 minutes } \\
\text { every other } \\
\text { week during } \\
\text { team planning } \\
\text { period } \\
\text { - Occasional } \\
\text { before and after } \\
\text { school sessions } \\
\text { - ISE sessions } \\
\end{array}$ \\
\hline $\begin{array}{l}\text { Spring } \\
2011\end{array}$ & $\begin{array}{l}\text { 30-40 minutes } \\
\text { every other } \\
\text { week during } \\
\text { team planning } \\
\text { period } \\
\text { Occasional } \\
\text { before and after } \\
\text { school sessions } \\
\text { - ISE sessions } \\
\end{array}$ & $\begin{array}{ll}\text { - } & \text { 30-40 minutes } \\
\text { every other } \\
\text { week during } \\
\text { team planning } \\
\text { period } \\
\text { Occasional } \\
\text { before and after } \\
\text { school sessions } \\
\text { - } \text { ISE sessions } \\
\end{array}$ & $\begin{array}{l}\text { 30-40 minutes } \\
\text { every other } \\
\text { week during } \\
\text { team planning } \\
\text { period } \\
\text { Occasional } \\
\text { before and after } \\
\text { school sessions } \\
\text { - ISE sessions } \\
\end{array}$ & $\begin{array}{ll}\text { - } & \text { 30-40 minutes } \\
\text { every other } \\
\text { week during } \\
\text { team planning } \\
\text { period } \\
\text { - Occasional } \\
\text { before and after } \\
\text { school sessions } \\
\text { - ISE sessions } \\
\end{array}$ \\
\hline & $\begin{array}{ll}\text { - } 30-40 \text { minutes } \\
\text { every other } \\
\text { week during } \\
\text { team planning } \\
\text { period } \\
\text { Occasional } \\
\text { before and after } \\
\text { school sessions } \\
\text { - ISE sessions } \\
\end{array}$ & $\begin{array}{ll}\text { - } & \text { 30-40 minutes } \\
\text { every other } \\
\text { week during } \\
\text { team planning } \\
\text { period } \\
\text { - Occasional } \\
\text { before and after } \\
\text { school sessions } \\
\text { - } \text { ISE sessions } \\
\end{array}$ & $\begin{array}{ll}\text { - } & \text { 30-40 minutes } \\
\text { every other } \\
\text { week during } \\
\text { team planning } \\
\text { period } \\
\text { - Occasional } \\
\text { before and after } \\
\text { school sessions } \\
\text { - } \quad \text { ISE sessions } \\
\end{array}$ & $\begin{array}{l}\text { - 30-40 minutes } \\
\text { every other } \\
\text { week during } \\
\text { team planning } \\
\text { period } \\
\text { Occasional } \\
\text { before and after } \\
\text { school sessions } \\
\text { - ISE sessions } \\
\end{array}$ \\
\hline $\begin{array}{l}\text { Spring } \\
2012\end{array}$ & $\begin{array}{ll}\text { - } & 30-40 \text { minutes } \\
\text { once per month } \\
\text { during team } \\
\text { planning period } \\
\text { - } \quad \begin{array}{l}\text { Occasional } \\
\text { before and after }\end{array} \\
\text { school sessions } \\
\text { - } \quad \text { ISE sessions }\end{array}$ & 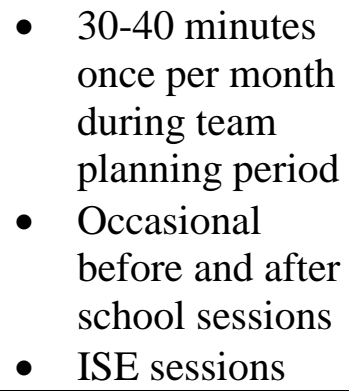 & $\begin{array}{ll}\text { - } & 30-40 \text { minutes } \\
\text { once per month } \\
\text { during team } \\
\text { planning period } \\
\text { - } & \text { Occasional } \\
\text { before and after } \\
\text { school sessions } \\
\text { - }\end{array}$ & 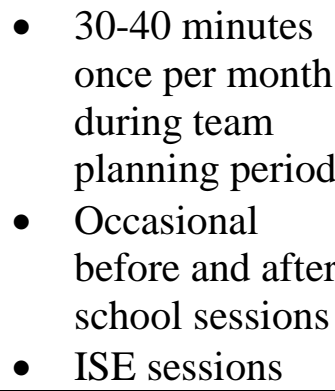 \\
\hline
\end{tabular}




\section{Data Sources and Instruments}

To answer the research question, five data sources were used, including teacher surveys, interviews, observations, discussion groups, and artifacts. While all teachers in the school were solicited to complete teacher surveys, record formal interviews, and participate in discussion groups, members of the Implementation Team received much of the focus due to the phased-in nature of the grant. Each of the data sources are described below, as well as data collection procedures and analysis procedures. Table 4 summarizes each data source.

Teacher surveys. Teacher surveys were conducted in an effort to obtain information regarding instructional practices and appropriate professional development. These surveys were administered during the first nine weeks of the 2010-2011 school year and the end of the 20112012 school year to all of the school's staff. Electronic surveys were delivered to instructors through the school's learner management system (Edline). Open response questions were used in an effort to gather adequate information. The teachers' survey responses were exported to an Excel file and saved by the date they were collected. Survey responses were analyzed for common themes; each response was coded by theme and then tallied to determine which themes reoccurred most frequently. The surveys included before and after versions of the following questions:

- How do you foresee the laptops being used in your classroom?

- What impact will a classroom set of laptops have on your instructional practices?

- What impact will a classrooms set of laptops have on the rigor and relevance of content?

- What impact will a classrooms set of laptops have on student achievement?

- What will be the impact on your individual classroom culture?

- What obstacles do you see to full implementation of one-to-one computing? 
Interviews. Classroom teachers from all grade levels and content areas, (not limited to those providing the first phase of 1:1 computing), were interviewed during the second semester of 2010-2011 and the second semester of 2011-2012 regarding professional development needs and school-wide policies. Formal interviews were recorded and transcribed, while informal discussions were paraphrased in anecdotal notes. Each formal interview was saved electronically as an mp4 file and as a transcribed Word document with the name of the instructor and date of the interview. Much like the survey responses, the interviews were analyzed for common themes; each response was coded by theme and then tallied to determine which themes reoccurred most frequently. Interviews consisted of before and after versions of the following questions:

- What changes will you make to your content delivery in a 1:1 computing environment?

- What changes will you make to your classroom management in 1:1 computing environment?

- On what topics do you feel you need professional development, in order to facilitate a 1:1 computing environment?

- What concerns do you have regarding implementing a 1:1 computing environment in your classroom?

Observations. Formal and informal classroom observations were conducted by the primary researcher, the school's TIS/Academic Coach. Formal observations took place in the classrooms of the teachers from the Implementation Team (the first six teachers to receive classroom sets of laptop computers). The observer took hand-written field notes that were titled with a teacher alias to protect confidentiality. Observations were conducted during the first and second semesters of the 2010-2011 school year, in an effort to discover the following: 
- How the laptops are being used within individual classrooms

- What changes have been made to classroom instruction

- What professional development needs to be provided in order to make the content delivery and classroom management more efficient

In addition to observations conducted by the TIS, classroom teachers made observations and provided anecdotal information regarding their individual and school-wide needs. As with the surveys and interviews, observations and anecdotal records were analyzed for recurring themes.

Discussion and Focus groups. Teams of teachers met regularly to discuss professional development and school-wide policy needs. Grade level teams met daily to discuss school and grade-level concerns. The school and county TIS periodically met with the grade level teams in an attempt to better understand their needs. Additionally, members of the school's "Implementation Team," shared key points from the grade level team meetings during regular Implementation Team meetings. The Implementation Team met once per month after school to share their progress and concerns. Anecdotal notes from these meetings were used to guide professional development planning.

Artifacts. Teacher resources used to record or manage a student-centered classroom design were collected. These classroom resources, along with materials from professional development sessions, including agendas and calendars for professional development, were collected and analyzed as to purpose, use, and benefits of each artifact. Additionally, screenshots from teachers' electronic pages on the school's learner management system (LMS) were taken in the spring of 2011 and the spring of 2012 and saved by teacher name and date. The screenshots were later compared to assess the changes in content and activities provided to students electronically. 
Table 4: Data Collection Sources

RQ: What are the appropriate professional development sessions and instructional design process needed in order to transform traditional classrooms into student-centered $21^{\text {st }}$ century classrooms?

\begin{tabular}{|c|c|c|c|}
\hline Data source & Purpose & $\begin{array}{c}\text { Data collection } \\
\text { procedures }\end{array}$ & Data analysis procedures \\
\hline $\begin{array}{l}\text { Teacher } \\
\text { surveys }\end{array}$ & $\begin{array}{l}\text { used to shape and } \\
\text { guide changes in } \\
\text { professional } \\
\text { development } \\
\text { content and } \\
\text { delivery methods }\end{array}$ & $\begin{array}{l}\text { electronic surveys } \\
\text { through the school's } \\
\text { learner management } \\
\text { system (Edline) }\end{array}$ & $\begin{array}{l}\text { surveys were exported to an } \\
\text { Excel file, saved by date, and } \\
\text { analyzed for recurring } \\
\text { themes }\end{array}$ \\
\hline $\begin{array}{l}\text { Teacher, } \\
\text { administrator, } \\
\& \text { technology } \\
\text { staff } \\
\text { interviews }\end{array}$ & $\begin{array}{l}\text { used to shape and } \\
\text { guide changes in } \\
\text { professional } \\
\text { development } \\
\text { content and } \\
\text { delivery methods }\end{array}$ & $\begin{array}{l}\text { audio recorded interviews } \\
\text { and informal discussions } \\
\text { with the school's } \\
\text { instructors, } \\
\text { administrators, and } \\
\text { technology staff }\end{array}$ & $\begin{array}{l}\text { interview notes and } \\
\text { recordings were analyzed for } \\
\text { recurring themes }\end{array}$ \\
\hline $\begin{array}{l}\text { Classroom } \\
\text { observations }\end{array}$ & $\begin{array}{l}\text { conducted in an } \\
\text { attempt to gain } \\
\text { greater } \\
\text { understanding of } \\
\text { the outcomes }\end{array}$ & $\begin{array}{l}\text { direct observation of } \\
\text { classroom structure and } \\
\text { management; anecdotal } \\
\text { observations were } \\
\text { gathered from instructors }\end{array}$ & $\begin{array}{l}\text { observation notes were } \\
\text { analyzed for recurring } \\
\text { themes across all } \\
\text { observations }\end{array}$ \\
\hline $\begin{array}{l}\text { Teacher } \\
\text { discussion and } \\
\text { focus groups }\end{array}$ & $\begin{array}{l}\text { used to shape and } \\
\text { guide changes in } \\
\text { professional } \\
\text { development } \\
\text { content and } \\
\text { delivery methods }\end{array}$ & $\begin{array}{l}\text { group discussions directly } \\
\text { observed by researcher or } \\
\text { reported on by members } \\
\text { of the focus group }\end{array}$ & $\begin{array}{l}\text { discussion notes were } \\
\text { analyzed for recurring } \\
\text { themes across all groups }\end{array}$ \\
\hline Artifacts & $\begin{array}{l}\text { collected and } \\
\text { analyzed for their } \\
\text { effectiveness }\end{array}$ & $\begin{array}{l}\text { teacher lesson plans, } \\
\text { posts to learner } \\
\text { management system } \\
\text { (Edline), graphic } \\
\text { organizers to assist } \\
\text { classroom transformation, } \\
\text { professional development } \\
\text { agendas and handouts, } \\
\text { TIS calendars }\end{array}$ & $\begin{array}{l}\text { artifacts were analyzed for } \\
\text { need, change over time, } \\
\text { organization techniques, and } \\
\text { other themes may have } \\
\text { manifested }\end{array}$ \\
\hline
\end{tabular}




\section{Data Collection Timeline}

Each data source was collected across both school years. Table 5 visualizes the collection of data during the study period.

Table 5: Timeline of Data Collection

\begin{tabular}{|c|c|c|c|c|}
\hline Data Source: & Fall 2010 & Spring 2011 & Fall 2011 & Spring 2012 \\
\hline $\begin{array}{l}\text { Teacher } \\
\text { surveys }\end{array}$ & September 2010 & & & May 2012 \\
\hline Interviews & Informal--ongoing & $\begin{array}{l}\text { Informal--ongoing } \\
\text { Formal--May } \\
2011\end{array}$ & Informal--ongoing & $\begin{array}{l}\text { Informal--ongoing } \\
\text { Formal--May } \\
2012\end{array}$ \\
\hline Observations & November 2010 & April 2011 & November 2011 & April 2011 \\
\hline $\begin{array}{l}\text { Discussion } \\
\text { and focus } \\
\text { groups }\end{array}$ & $\begin{array}{l}\text { Monthly } \\
\text { Implementation } \\
\text { Team meetings } \\
\text { Daily grade level } \\
\text { team meetings } \\
\text { Weekly } \\
\text { technology } \\
\text { professional } \\
\text { development with } \\
\text { all grade level } \\
\text { teams }\end{array}$ & $\begin{array}{l}\text { Monthly } \\
\text { Implementation } \\
\text { Team meetings } \\
\text { Daily grade level } \\
\text { team meetings } \\
\text { Bi-weekly } \\
\text { technology } \\
\text { professional } \\
\text { development with } \\
\text { all grade level } \\
\text { teams }\end{array}$ & $\begin{array}{l}\text { Daily grade level } \\
\text { team meetings } \\
\text { Bi-weekly } \\
\text { technology } \\
\text { professional } \\
\text { development with } \\
\text { all grade level } \\
\text { teams }\end{array}$ & $\begin{array}{l}\text { Daily grade level } \\
\text { team meetings } \\
\text { Monthly } \\
\text { technology } \\
\text { professional } \\
\text { development with } \\
\text { all grade level } \\
\text { teams }\end{array}$ \\
\hline Artifacts & $\begin{array}{l}\text { On-going: } \\
\text { Collected } \\
\text { throughout the } \\
\text { year }\end{array}$ & $\begin{array}{l}\text { On-going: } \\
\text { Collected } \\
\text { throughout the } \\
\text { year }\end{array}$ & $\begin{array}{l}\text { On-going: } \\
\text { Collected } \\
\text { throughout the } \\
\text { year }\end{array}$ & $\begin{array}{l}\text { On-going: } \\
\text { Collected } \\
\text { throughout the } \\
\text { year }\end{array}$ \\
\hline
\end{tabular}




\section{Limitations of Methodology}

The WVDE EETT grant that provided the funding for one-to-one computing dictated a phased-in approach. For this reason, only six teachers were observed implementing one-to-one computing during the first year of this study. Despite this, all staff was provided the same professional development opportunities and many of those who were not on the Implementation Team found it easier to access the school's stationary computer labs with an increase in classroom computers.

Conducting this study in a public school created some additional limitations. The existing schedule created an inequity in the number of professional development session that could be provided to core content teachers and related arts specialists. Fortunately, the related arts teachers were able to meet once per week before school started and received the same professional development opportunities every other week.

Finally, it is important to note that this study required observations in classrooms containing minor children. The observations focused solely on the classroom methods of the classroom instructors. No student names were used in field notes and teacher names were replaced with aliases on hand-written notes to protect confidentiality.

Table 6 itemizes the limitations of the study and the strategies used to address each limitation. 
CENTERED $21^{\text {ST }}$ CENTURY CLASSROOMS

Table 6: Study limitations and strategies to circumvent

\begin{tabular}{|l|l|}
\hline Limitation & Strategy to Circumvent \\
\hline $\begin{array}{l}\text { Due to the nature of the EETT } \\
\text { grant, only six teachers were } \\
\text { observed implementing 1:1 } \\
\text { computing during the 2010- } \\
2011 \text { school year. }\end{array}$ & $\begin{array}{l}\text { Professional development was provided for all staff } \\
\text { members. }\end{array}$ \\
$\begin{array}{l}\text { Interviews and teacher surveys assisted me in gaining } \\
\text { further information and making generalizations to a larger } \\
\text { population. }\end{array}$ \\
\hline $\begin{array}{l}\text { Unlike the grade level teams } \\
\left(6^{\text {th }}, 7^{\text {th }}, \text { and } 8^{\text {th }} \text { grade teachers }\right), \\
\text { the related arts teachers did not } \\
\text { have a common team planning } \\
\text { period with which to participate } \\
\text { in professional development. }\end{array}$ & $\begin{array}{l}\text { access to the school's computer labs for the rest of the } \\
\text { staff. }\end{array}$ \\
\hline $\begin{array}{l}\text { The related arts teachers met before school once per week } \\
\text { to discuss school-wide issues. } \\
\text { Related arts teachers were provided with professional } \\
\text { development every other week, instead of once per week. } \\
\text { Materials and important information from grade level } \\
\text { teams' professional development was posted on the } \\
\text { that observations will be } \\
\text { conducted in a classroom of } 28- \\
30 \text { minor students. }\end{array}$ & $\begin{array}{l}\text { school's learner management system (Edline) for use by } \\
\text { the related arts teachers. }\end{array}$ \\
\hline $\begin{array}{l}\text { Confidentiality was maintained throughout the study in } \\
\text { order to ensure that no harm would come to the students in } \\
\text { the instructors' classrooms. }\end{array}$ \\
\hline
\end{tabular}

\section{Summary of Methodology}

This design-based action research study allowed the utilization of an instruction design model of design, implementation, and evaluation across four school semesters to improve the professional development provided to teachers in a new one-to-one computing environment. Data sources collected across all semesters, as well as the initial needs assessment, helped guide changes to the design and implementation phases of the professional development plan. 
CENTERED $21^{\text {ST }}$ CENTURY CLASSROOMS

$$
\text { Chapter IV - Findings }
$$

\section{0-2011 Semester I}

Design. While planning professional development during the first semester of the school's transition to one-to-one technology, it was important to keep in mind the overall goal of the project. The teachers, administration, and support staff who served on the grant writing committee had a very clear mission to develop students' $21^{\text {st }}$ century learning and thinking skills. One-to-one technology was merely one tool that they intended to use to achieve that goal. Most of the school staff was aware of that goal and had heard "buzz" words such as "studentcentered", "teacher-as-facilitator", and "project-based learning" throughout the grant-writing process.

For that reason, it was no surprise to find these and similar phrases appear frequently throughout the initial needs assessment survey conducted in the fall of 2010. According to the initial survey, a large number of teachers in the school found these to be the desired outcomes from the one-to-one transformation. These survey results directly influenced the planning of the professional development sessions for the fall 2010 semester; if teachers were interested in transforming to student-centered classrooms, then professional development would focus on the resources and methods to do so. Table 7 details the most frequent themes emerging from each data source. The frequency of each theme appearing in surveys can be found in Table 11.

The school had an existing structure in which grade-level teams met daily to collaborate in Professional Learning Communities (PLC). Due to the school-day schedule, related arts teachers were only able to meet weekly for PLC meetings. Professional development sessions were designed around this existing structure by providing sessions during PLC meetings once per week for grade-level teams and once every other week for the related arts team. In addition 
to the existing PLC meetings, the group of teachers who had been selected as the first in the building to receive classroom sets of laptops, known as the Implementation Team, would meet monthly after school to discuss their progress and needs.

Finally, during the first semester of the two-year transformation, no student laptops were distributed. All full-time teachers were provided with a teacher laptop for professional use to encourage the exploration of resources.

Implementation. During the first meetings with grade-level PLCs, it became apparent that initial understanding from the needs assessment surveys needed to be re-evaluated. While the surveys indicated that an overwhelming number of teachers wanted assistance moving towards constructivist methods, face-to-face meetings with grade-level teams revealed that each team had very different expectations and needs.

As a whole, the eighth grade team felt that they were already exhibiting constructivist teaching methods; all they needed was the laptops to push their methods to the "next level". The first professional development session was formatted as a discussion group. The results of the needs assessment survey were shared with the team and suggestions for reaching the apparent school-wide goal of student-centered learning were solicited. During this session, members of the eighth grade team continually brought the conversation back around to logistical concerns. They were more interested in how they would rearrange their classrooms and the location of the classroom electrical outlets than discussing teaching methods. Additionally, when asked what needs they had for professional development sessions, among the responses were "student laptop contracts", "policies for repeat offenders", and "an easier method to type math symbols". While all of those topics needed to be discussed, they were not the expected direction for the first meeting. 
The seventh grade team seemed to have the most difficulty imagining the transformation. During their first session wherein they were provided with the survey results and suggestions for professional development were solicited, members of the team were non-committal in regards to their needs and desires. Finally, Mrs. Archer", a member of the Implementation Team, said "I just need to see it in action. I don't know what to expect." At this point other members of the team agreed with her indicating that while they had been hearing about transforming to a one-toone computing environment and utilizing project-based learning, they were still unsure about what that meant for their classrooms. They could not predict what professional development they needed until they had a better understanding of what it meant to be student-centered.

The first meeting with the sixth grade was the most enlightening in understanding the direction of professional development. Upon sharing the anonymous survey results, Ms. Patel offered that she had been the author of a particular comment and it was a concern that she would like to discuss. On the survey, Ms. Patel expressed a concern that in a one-to-one computing environment, students would have "less social interaction" and that "some cooperative skills may be lost". This came as a surprise since the overwhelming theme from the survey indicated that most teachers wanted to transform to student-centered projects. In order to better understand her concern, the sixth grade team members were asked to describe the laptop activities they imagined utilizing in their classroom. The majority of the team members described traditional teacher-centered activities that simply replaced paper, pencil, and textbooks with a computer. Some suggestions included "doing worksheets and study guides on the computer to fill in answers", "typing notes instead of writing them", "viewing PowerPoints at their seat instead of the front of the room to increase focus", and "completing writing tasks on a computer instead of

\footnotetext{
${ }^{1}$ All names within this text are pseudonyms.
} 
paper". It was apparent that although this team had heard the school-wide discussion about moving towards a student-centered environment, much like the seventh grade team, they did not understand the impact on their classrooms.

It was apparent that Mrs. Archer was right, they needed to see the results of a transformation in action. However, while Mrs. Archer was simply concerned with seeing one-toone computing in action, it was more important that the teams see constructivist teaching with some technology integration. For the second professional development session, each team was shown a TED Talk video (2010) in which the presenter, Sugata Mitra, presents a series of problems to a groups of 3-4 elementary aged students. In the video, the students work cooperatively with one computer to solve the problems without any further direction from the adults. Following the viewing of the video, each team discussed the implications in their classrooms. It was at this point that Ms. Patel, the teacher who feared a loss of socialization, interjected "I get it now!” Actually seeing students working collaboratively and aided by technology to solve problems, made the theoretical discussions real to Ms. Patel and the other teachers who needed to see it before they could imagine the changes to their own classrooms.

Professional development sessions for the remainder of the semester focused primarily on introducing the teachers to technology resources and discussing how such resources could be integrated into their individual curriculums. Resources were presented in a hands-on manner. Teachers were expected to bring their teacher laptops to the professional development session and explore the resources that were presented. During each session, time was also provided to discuss their current needs or concerns. Because student laptops would not begin to be distributed until the following semester, it was rare that a need was expressed by anyone who was not on the Implementation Team. 
The Implementation Team continued to meet monthly to discuss preparations for the second phase of the laptop implementation. During the second semester, the members of the Implementation Team would receive a classroom set of laptops. Unlike the grade-level team professional development sessions, the Implementation Team meetings were not a time to explore or share resources. Instead, the time was devoted to sharing, discussing, and questioning classroom methods, procedures, expectations, and concerns. While there were two members from each grade level on the Implementation Team, the most vocal members of this committee were both from the eighth grade, one social studies teacher and one English teacher. As such, the conversation was dominated by their grade-level's vision of laptop implementation. Both of the sixth grade members and one of the seventh grade members of the Implementation Team, all three science teachers, shared a similar vision of student collaboration. One member of the committee, Mrs. Archer, was comparatively quiet during the Implementation Team meetings, but appeared to be in agreement with the direction that the committee had taken. A few weeks before the laptops were expected to be placed in the classrooms, Mrs. Archer privately shared some concerns. She was visibly upset and worried because she was uncomfortable with the direction that the Implementation Team had taken. Specifically, all of the other members of the Implementation Team wanted tables in their classrooms to facilitate student collaboration and she wasn't certain that she wanted to give up individual desks. It became clear that as a member of the Implementation Team, she felt pressured to conform to the perceived school-wide expectations. After a one-on-one discussion about her personal vision for her transformed classroom, she came to the realization that she could meet the school-wide expectation of student-centered instruction, while still maintaining her individual teaching beliefs. 
Towards the end of the semester, as initial implementation drew closer, each grade-level team was asked to brainstorm a list of procedures and policies that they felt were necessary when using laptops in the classroom. The grade-level lists of expectations were examined by the Implementation Team and edited to create one school-wide set of policies and procedures. The team felt strongly that the expectations should be consistent across all classrooms and gradelevels to ensure that students understood and followed the expectations. In addition to creating clear expectations for the students, this also created guidelines for the staff to follow and provided some security for those teachers who needed to focus on the logistics of implementation.

Evaluation. The end of the first semester marked the end of theoretical implementation. The laptop carts would roll out to six classrooms at the beginning of the following semester. Reflection of the professional development during the first semester began to illustrate what worked for this group of teachers and what needed to be tweaked. Already, it was apparent that collaboration was a necessary for the success of the transformation. All three grade-level teams had begun to share, plan, and discuss outside of weekly professional development sessions. Additionally, teachers were sharing ideas vertically through content area meetings as well. This was particularly true of science and English teachers who often met informally to discuss ideas for activities and lessons.

During the first semester, it became apparent that not everyone had the same vision of transformation. While some needed only reassurance that there were multiple ways to do things, others needed to be shown what $21^{\text {st }}$ century skills looked like. Although it was not in the original plan for professional development, restating the school-wide goals and providing a visual depiction of the final product was necessary. In retrospect, the need to see constructivism 
in action actually reinforced the phased-in approach that the school was taking with the laptop implementation. Teachers needed to see others utilizing these tools successfully in order to both understand the school-wide vision and to embrace change in their own classroom.

When designing and envisioning professional development sessions for the first semester, it was expected that the majority of the time would be spent sharing resources and teaching methodology with the teacher-learners. While this was a common occurrence, more time was actually spent discussing logistical concerns, such as classroom arrangement and storage. Looking back, these were necessary components to assuage fears over change and helped provide action steps that teachers could take immediately.

Table 7: Recurring Themes for Each Data Source during 2010-2011 Semester 1

\begin{tabular}{|l|l|}
\hline Data Source & Recurring Theme(s) \\
\hline \multirow{5}{*}{ Surveys } & 1. Student engagement \\
& 2. Teacher as facilitator \\
& 3. Student-student collaboration \\
& 4. Student as researcher \\
& 5. Differentiation \\
\hline Interviews (formal) & None: no formal interviews were conducted during this semester \\
\hline Interviews & 1. Finding new resources (time) \\
(informal/anecdotal) & 2. Logistical concerns \\
\hline \multirow{5}{*}{ Discussion/focus groups } & 3. Policies \\
\hline \multirow{5}{*}{ Observations } & 2. Time (locating resources and teacher-teacher collaboration) \\
& 3. Procedures \\
& 4. Policies \\
\hline \multirow{3}{*}{ Artifacts } & 1. Student-student collaboration \\
& 2. Note-taking \\
& 3. Direct instruction \\
& 4. Project-based learning \\
\hline
\end{tabular}




\section{0-2011 Semester II}

Design. The spring semester of the 2010-2011 school year was the first semester in which teachers received classroom sets of laptop computers. Driven by experiences from the first semester, it was decided that the planned method of professional development delivery would be continued. During the spring semester, grade-level teams would receive professional development every other week and the Implementation Team would continue to meet monthly.

At this point in the school year, policies and procedures were in place for student handling and utilization of the laptops, logistics such as charging stations and room arrangements had been selected, and teacher buy-in appeared to be established. For that reason, the content during professional development sessions was planned around resources and transitioning to project-based learning.

Implementation. Throughout the second semester, professional development sessions were provided with grade-level teams every other week, as planned. During that time, teachers were highly receptive to sessions that allowed them time to explore online resources. As teachers explored resources, discussion naturally occurred among team members. Teachers would be overheard discussing their plans for using the resources presented, suggesting uses to peers, and planning cross-curricular activities using the resources.

The idea of collaborating with peers really began to take hold during the spring semester. Discussions regarding cross-curricular projects and thematic planning began to occur more regularly in the eighth and sixth grade team meetings. Similarly, all three grade levels found that the two teachers on each team who had received classrooms sets of laptops were now considered implementation experts. They were sought out and asked to discuss their experiences regularly 
both in and out of grade-level team meetings. As fellow teachers were preparing for their turn with the laptops, they wanted advice from those who had already attempted the transition.

It was during this semester that the level of fear and anxiety was noticeably lowered, thus eliminating the need to discuss logistical concerns during professional development sessions. Teachers saw members of the Implementation Team have success transitioning and began to believe that they were ready to make changes too. Gone also were the concerns over room arrangements and the need for tables to replace desks. Mrs. Archer had proven that she did not need tables to successful integrate technology, nor did she need to utilize the same classroom arrangement to encourage collaborative learning activities.

The monthly Implementation Team meetings began to change their focus from "What do I need to do to be prepared for one-to-one technology?" to "What do they need to do to be prepared for one-to-one technology?" Team members began reflecting on the changes they had made, both expected and unexpected, to share with the rest of the staff in order to better prepare them to make changes to their content delivery. The overwhelming theme seemed to be time. It was already apparent that they needed time to collaborate and time to explore resources, but the team members stressed that the were unprepared for amount of time necessary to plan and implement projects. While they felt the projects were beneficial and led students to higher level thinking skills, they feared that some of their peers would be turned off to changing their teaching methods once they realized the time commitment to a project.

Evaluation. As the second semester came to an end, participants were interviewed regarding their growth, the changes in their classrooms, and the direction of professional development throughout the past year. Additionally, data was collected from the school's learner management system to inform how the LMS was being used by teachers throughout the 
school. Table 8 details the most frequent themes emerging from each data type collected during the second semester. Table 12 indicates the frequency at which each theme occurred during interviews. The frequency of themes and purposes emerging from the learner management system can be seen in Table 13.

Analysis of the learner management system showed that most teachers in the building were using the LMS to report grades and share resources, such as class notes, with students. A small portion of teachers, primarily those who had begun one-to-one implementation, were utilizing the platform to provide blended delivery through the use of online quizzes, assignments, and discussion boards. There was very little indication from analyzing the teachers' LMS sites that they were using the platform to differentiate or provide opportunities for student collaboration. Examining the platform provided evidence that the teachers who had the capability of blending instruction regularly were willing to do so, but were doing so while modeling traditional classroom techniques; they had not yet embraced the learner management system to deliver student-centered instruction.

Unlike the findings from the LMS, teacher interviews indicated that there was a classroom shift occurring. Multiple teachers indicated that they found differentiation easier in a one-to-one computing environment. Mrs. Scott, a sixth grade science teacher, was particularly excited by this revelation when she noted the following:

It freed me to go from group to group or child to child and be able to talk and actually interact more than had we not had them. There's more of the student taking ownership of their own learning. There's more ease in differentiation. For example, there was one science simulation we were using and I was able to go to different students and sit down and talk with them and let them tell me what they were doing and it was a much better 
assessment than I could have gotten paper/pencil or even just reading a lab sheet because as they came up with answers, I could delve further into it. I felt I had a much better, clearer, understanding of what they were understanding or where they were having problems.

Similar experiences were noted by teachers at other grade levels as well. Mrs. Todd, an eighth grade social studies teacher, highlighted the change in her classroom by indicating that students were able to take ownership of their learning:

The classroom culture has changed to where I am no longer the end-all-be-all. I'm now just the facilitator. It has allowed the student to become the teacher, more so than them just believing that everything I say is just the gospel truth.

Another eighth grade teacher, Mrs. Adams, pointed out that as the students became comfortable in a student-centered environment, they began to see the computers as simply another tool to aid their learning and progress. She commented, "They feel more comfortable just going and getting them and pulling them out to do something. It's like having a textbook available in the classroom. It's another resource in the classroom that they feel free to use."

During interviews, teachers also commented on their own growth in regards to their comfort level making such transitions. Mrs. Archer reflected on her concerns and distress during the first semester and stated

I've had to learn to be more flexible and to not worry so much. I think a lot of the things that I worried about, looking back now, they seem silly and I don't really worry about it. If there is something that comes up, I just deal with it and move on. Like dropping a laptop or running out of battery, so many little things that I stressed about, my classroom set up, logistical concerns, all of the little things, planning and day-to-day basics. Things 
will happen and it's okay. It's been a learning process, but I think it's just getting better and better and I'm excited for next year.

Mrs. Cooper, a sixth grade teacher, made a similar note about being flexible when she provided the following advice for teachers who would be implementing one-to-one technology for the first time the following semester:

The technology is your tool. It's a way to get to someplace else. It's not the be-all-endall. Take it in baby steps, because you can build on baby steps and you'll have what you want in the end. You don't have to do it all immediately and think it has to be polish perfect. It's a work in progress.

Finally, the interviews reinforced the belief that collaboration among teachers was both desired and necessary. Throughout the interviews, teachers indicated that having the support of their peers was the greatest piece of the professional development that they were provided. Mrs. Todd summarized this prevailing opinion when she stated, "That was the key to success. Having the time to talk to your co-workers that were going through the same process or those who were about to go through the implementation was essential."

In analyzing the second semester, it is hard not to look at the year as a whole. The first group of teachers who implemented one-to-one computing benefitted greatly from time exploring resources and sharing strategies with peers. This collaboration was necessary during the first semester, before the technology was employed, and throughout the second semester, as teachers began attempting to utilize the technology in their classrooms.

While the second semester proved that teachers were ready to transform their classrooms into student-centered learning environments, it also showed that when it came to online delivery, teachers were still using traditional methods. 
CENTERED $21^{\text {ST }}$ CENTURY CLASSROOMS

Table 8: Recurring Themes for Each Data Source during 2010-2011 Semester 2

\begin{tabular}{|c|c|}
\hline Data Source & Recurring Theme(s) \\
\hline Surveys & None: no formal survey responses were solicited during this semester \\
\hline Interviews (formal) & $\begin{array}{l}\text { 1. Time (locating resources and teacher-teacher collaboration) } \\
\text { 2. Student engagement } \\
\text { 3. Differentiation } \\
\text { 4. Project-based learning } \\
\text { 4. Student as teacher } \\
\text { 5. Procedures } \\
\text { 5. Teacher flexibility } \\
\text { 5. Technical difficulties }\end{array}$ \\
\hline $\begin{array}{l}\text { Interviews } \\
\text { (informal/anecdotal) }\end{array}$ & $\begin{array}{l}\text { 1. Logistical concerns } \\
\text { 2. Blended delivery } \\
\text { 2. Finding new resources (time) } \\
\text { 3. Outside professional development }\end{array}$ \\
\hline Discussion/focus groups & $\begin{array}{l}\text { 1. Time (locating resources and teacher-teacher collaboration) } \\
\text { 2. Logistical concerns } \\
\text { 3. Project-based learning } \\
\text { 3. Procedures } \\
\text { 4. Differentiation } \\
\text { 5. Grading Practices }\end{array}$ \\
\hline Observations & $\begin{array}{l}\text { 1. Student-student collaboration } \\
\text { 2. Differentiation } \\
\text { 3. Note-taking } \\
\text { 3. Direct instruction }\end{array}$ \\
\hline Artifacts & $\begin{array}{l}\text { 1. Grading practices } \\
\text { 2. Note-taking } \\
\text { 3. Use of LMS for blended learning } \\
\text { 4. Procedures }\end{array}$ \\
\hline
\end{tabular}

\section{1-2012 Semester I}

Design. As the second year of the study began, experiences and reflections from the previous year drove the professional development plan. Success had been seen through collaboration among teaching teams with regular opportunities to discuss implementation issues and strategies. For that reason, it was determined that grade-level teams would continue to meet with the Technology Integration Specialist (TIS) every other week. The content of the sessions would continue to be driven by staff needs. Previous end of year surveys and other data 
collected, indicated that teachers should continue to be exposed to new resources and provided time to explore and collaboratively plan with new resources.

Because teachers seemed to benefit from having laptop implementation modeled through the phased-in approach, it was determined that teachers would continue receiving classroom sets of laptops as a cohort. This semester an additional six teachers were expected to receive laptops.

The six teachers beginning implementation this semester would need support as they began putting into practice the suggested classroom changes. For that reason, it was determined that professional development sessions should continue to encourage cooperative student learning and other constructivist teaching methods.

At the end of the previous year, data indicated that while teachers were shifting their face-to-face classroom teaching methods, they were remaining traditional with online class delivery. During this first semester of the second school year, it would be necessary to revisit the LMS platform during professional development sessions and share suggestions for creating an online student-centered learning environment.

Implementation. The first semester of the second year was plagued with technical difficulties. The second round of laptops received by the school contained faulty wireless cards, causing frequent disconnects from the school's virtual server and in many cases it was impossible for students to $\log$ in to the new computers at all. By the time the problem was identified and the new wireless cards were shipped and installed, the semester was almost over. When the laptop carts did finally roll out to their classrooms, a decision had been made to advance the final phase of the implementation and provide laptops to the teachers slated to receive them during this first semester of the year and the second semester of the year. 
During this semester many teachers became very frustrated as they tried to change their content delivery, but became distrustful of the technology tools they were asked to utilize.

Others showed amazing patience as they assisted the technicians with trials designed to pinpoint the problems and then test the thresholds once a solution was discovered. Whether they were frustrated by the technology or actively testing the limits, all of the teachers were forced to demonstrate the flexibility hinted at during the previous semester. Teachers were heard commenting that they made sure they had a plan A, plan B, and a plan C, because they weren't sure what aspects of the technology would be working each day.

At the start of the semester, several of the grade-level professional development sessions had to be cancelled due to the technical difficulties. Despite this, grade-level teams continued to discuss the school's progress and their concerns during daily meetings. A common occurrence during this time was for a teacher to express his or her frustration over not knowing how to plan a particular unit or lesson because he or she did not know what technology would be available. Typically this frustration led to grade-level conversations providing the teacher with alternative suggestions for lesson ideas. In this way, the technical difficulties and frustration became an impetus for creating collaboration, preparation, and change.

As the semester continued and working laptops were distributed among all of the core content teachers, trust began to replace their frustration and teachers again embraced the use of the laptops. Towards the end of this semester, related arts teachers, who had not been provided with classroom sets of laptops began utilizing the carts during the core teachers' planning periods. Both the physical education teacher and the Spanish teacher began borrowing the laptop carts to integrate technology into their lessons. 
Bi-weekly professional development sessions also resumed with the delivery of working laptop carts to the classrooms. Sessions completed at the end of this semester included a review of the blended learning capabilities of the learner management system and new resources that could be utilized in the classroom.

Evaluation. While technical difficulties caused some professional development sessions to be cancelled, those that were offered provided some enlightening information. It was during this semester that all core content teachers were provided with classrooms sets of laptops. For that reason, it was easier to see the effects of the professional development sessions, as they now were being applied by a greater number of teachers.

In the previous two semesters, teachers praised the idea of sharing online resources during professional development sessions. However, during this semester it became clear that providing only one resource during a session should be done so with caution. Teachers began to utilize the resources to the point of overkill. For example, if a new resource was shared with the eighth grade team, it was not unusual for the reading teacher, the science teacher, the social studies teacher, and the English teacher to try it with their classes immediately. This caused the students to burn out on the resource and not want to use it when they were given the option. Additionally, the use of the resource did not appear to be organic to a need; when all of the teachers used it at the same time, use of the resource seemed forced and isolated, and did not demonstrate real-world reasons to use such a resource.

As the semester came to an end, one teacher proved that despite the problematic start to the year, teachers were actually changing their beliefs and their classroom teaching methods. Ms. Patel, the sixth grade teacher who stated during the first semester that students would lose 
socialization skills as they completed their worksheets and watched PowerPoints individually at their seats, shared the following:

I can't tell you how much better and richer my teaching is because of those laptops. The kids are focused, tuned in. I am less stressed. When I used them all day, every class was less stressful, calmer; they were on task. I didn't have to motivate them, they were motivated. I also feel like when I use the laptops, the kids' opinion of my abilities is elevated. I love them, even when they are not working! They have changed my teaching for the better.

Ms. Patel went on to explain that she felt she was able to provide higher leveling thinking opportunities for her students due to the inclusion of technology in her classroom. The engagement of her students in the student-centered activities she had given them had created an environment where they were involved in more analysis and evaluation tasks than ever before.

Despite the rocky start to the semester, it provided some informative data. Teachers were still opting to collaborate and learn from one another. A community of learners had emerged that allowed teachers to feel comfortable venting their frustrations, and others comfortable offering suggestions. Additionally, it became apparent that while providing resources was still desired, it needed to be done strategically. 
CENTERED $21^{\text {ST }}$ CENTURY CLASSROOMS

Table 9: Recurring Themes for Each Data Source during 2011-2012 Semester 1

\begin{tabular}{|c|c|}
\hline Data Source & Recurring Theme(s) \\
\hline Surveys & None: no formal survey responses were solicited during this semester \\
\hline Interviews (formal) & None: no formal interviews were conducted during this semester \\
\hline $\begin{array}{l}\text { Interviews } \\
\text { (informal/anecdotal) }\end{array}$ & $\begin{array}{l}\text { 1. Technical difficulties } \\
\text { 2. Blended delivery } \\
\text { 2. Logistical concerns }\end{array}$ \\
\hline Discussion/focus groups & $\begin{array}{l}\text { 1. Technical difficulties } \\
\text { 1. Finding new resources (time) } \\
\text { 2. Student ownership of learning } \\
\text { 3. Procedures } \\
\text { 4. Differentiation }\end{array}$ \\
\hline Observations & $\begin{array}{l}\text { 1. Technical difficulties } \\
\text { 2. Blended learning } \\
\text { 2. Student as researcher } \\
\text { 3. Student as teacher } \\
\text { 4. Direct instruction } \\
\text { 4. Note-taking }\end{array}$ \\
\hline Artifacts & $\begin{array}{l}\text { None: themes from meeting agendas and calendars included in } \\
\text { discussion groups, observations, and anecdotal notes }\end{array}$ \\
\hline
\end{tabular}

\section{1-2012 Semester II}

Design. As the second semester of the second year began, all core content teachers were utilizing one-to-one computing in their classrooms. As such, no teachers in the building were preparing for a transition to one-to-one computing. For this reason, it was no longer necessary to meet every other week and instead professional development sessions were held monthly for grade-level teams. This change in need, combined with reflections from the previous school year and the previous semester, drove the professional development plan.

The previous semester had illustrated a need to reevaluate the method and frequency in which new resources were shared with instructors. While teachers appreciated the introduction to such resources, the sites became overused across multiple content areas. To combat this, professional development sessions would be thematic and include multiple resources to achieve the same objective. For example, one professional development session would focus on 
presentation methods, at which time teachers would be introduced to multiple ways that students could present projects.

As with all previous semesters, teachers would be encouraged to share concerns and suggestions during these structured professional development sessions, daily team meetings, and informal collaboration. Given the problems encountered with the equipment during the prior semester, this collaboration had proven to be a necessary component.

Implementation. Unlike the semester before, this final semester of the study was implemented as planned. Grade-level teams met for professional development sessions monthly, while continuing to plan and problem-solve during daily meetings. Collaboration became more organic, as teachers discussed the technology when issues arose or when discoveries were made. Teachers often came to team meetings and stated, "Let me tell you what I learned today..." as an opening to share a shortcut, program, or problem encountered during a class period.

During this semester, professional development sessions became a time for teachers to explore. At the start of the semester, the school took part in a Continuing Education day, which gave the teachers an opportunity to meet by content area, instead of grade levels. At this time, teachers were provided with a database of online resources to explore. Together, the content area teams, explored the sites and offered suggestions to one another for their use. As a follow up to this session, a site was developed on the school's LMS for teachers to share and suggest resources they discovered with the rest of the staff.

Evaluation. As this semester came to an end, it was necessary to not only look back over the progress made during this portion of the study, but also the project implementation as a whole. At this time, all teachers were asked to complete an online survey regarding their utilization of the laptops in their classrooms, teachers were interviewed regarding laptop use and 
CENTERED $21^{\text {ST }}$ CENTURY CLASSROOMS

professional development sessions, and the learner management system was again analyzed for changes in instructional practices. Table 10 illustrates the most common themes appearing in each of these data sources. Tables 11,12 , and 13 note the frequency of each theme emerging from the surveys, interviews, and LMS analysis, respectively.

Analysis of the learner management system showed that throughout this school year, teachers were using the platform more robustly that the previous school year. While it was no surprise that the most common use of the platform was still for posting grades (after all, every teacher was required to post grades to the LMS), the frequency of usage for blended learning was almost equal to the frequency of usage for posting grades. Teachers across all grade levels, were utilizing the LMS for completing online assignments, taking quizzes, and holding online discussions. Additionally, analysis showed that there was an increase in online student-centered activities. The teachers' LMS sites showed evidence that they were using the platform to encourage project-based learning and student collaboration.

Teachers throughout the building were transforming to student-centered learning and focusing on teaching $21^{\text {st }}$ century skills. Across all three grade levels, teachers in English, reading, social studies, and science regularly provided opportunities for student choice in presentation and research methods. Not all choices were digital, despite having access to laptops in every classroom, students were still given the option to select analog resources; the students were given the freedom to select the best tool for the problem and the tool that best fit their individual learning styles. On the anonymous surveys completed at the end of the semester, teachers commented on the transformation that took place in their classrooms. One teacher stated: 
CENTERED $21^{\text {ST }}$ CENTURY CLASSROOMS

The computers have become just as much a part of the classroom as textbooks or any other learning tool. Students have learned to respect the computers, but also realize they are a learning tool. I feel this gives students a better appreciation for their resources and helps them understand what kind of skills they will need to have to keep up with our ever changing world.

Another teacher pointed out how the transformation in the classroom created an environment where the teacher had become the facilitator of learning, allowing the students to delve deeper into topics, "Instead of dishing out outdated material, I can bring current topics and information into my students' hands. I see evidence of higher level thinking skills (evaluation, analysis, etc.) in their questions and products."

While the prevailing opinion of these changes were positive, there were some members of the faculty who expressed concern regarding the changes they saw taking place throughout the building. The school's assistant principal feared that transforming middle school classrooms was not the best practice. While she agreed that the students were benefitting from the changes, she stated that "We are setting them up for failure because the way they learn here is not how they will learn in high school or college." As the purpose of this study is not to determine the level of benefit for the students, but to determine the benefit of the professional development for the teachers' transition, the assistant principal's comment is included only to illustrate that the teachers' beliefs and instructional practices were changing from traditional classroom methods.

As was found in previous semesters, teacher collaboration played a large part in the teacher interview responses. Almost every teacher interviewed commented on the importance of collaborating with peers and having time to explore resources with peers. Mrs. Adams, the 
eighth grade science teacher, pointed out that the collaboration and exploration time did not need to be formal professional development sessions in order to be effective:

What has helped me a lot is more of the informal professional development, where if I'm trying to plan a unit out I can go and ask "Help me brainstorm. This is what I want to do, do you have any ideas as to how I can do it?" Sharing with the other science teachers.

The seventh grade science teacher, when we have vertical teaming, we both are one-toone so she might find resources and I might find resources that she could use and we share them. It's not even necessarily waiting until we have vertical teaming, we're only one room away, so we can share every day, if we want to.

This thought was echoed by many teachers. Having someone with which to share and problemsolve, was a priceless piece of professional development necessary for transitioning classroom teaching methods. 
CENTERED $21^{\text {ST }}$ CENTURY CLASSROOMS

Table 10: Recurring Themes for Each Data Source during 2011-2012 Semester 2

\begin{tabular}{|c|c|}
\hline Data Source & Recurring Theme(s) \\
\hline Surveys & $\begin{array}{l}\text { 1. Technical difficulties } \\
\text { 2. Differentiation } \\
\text { 3. Student as researcher } \\
\text { 4. Student engagement } \\
\text { 5. Use of learner management system for blended learning }\end{array}$ \\
\hline Interviews (formal) & $\begin{array}{l}\text { 1. Time (locating resources and teacher-teacher collaboration) } \\
\text { 2. Procedures } \\
\text { 3. Student engagement } \\
\text { 3. Teacher as facilitator } \\
\text { 4. Differentiation } \\
\text { 4. Specific resource } \\
\text { 4. Student-student collaboration }\end{array}$ \\
\hline $\begin{array}{l}\text { Interviews } \\
\text { (informal/anecdotal) }\end{array}$ & $\begin{array}{l}\text { 1. Finding new resources (time) } \\
\text { 2. Blended delivery }\end{array}$ \\
\hline Discussion/focus groups & $\begin{array}{l}\text { 1. Finding new resources (time) } \\
\text { 2. Technical difficulties }\end{array}$ \\
\hline Observations & $\begin{array}{l}\text { 1. Technical difficulties } \\
\text { 1. Student-student collaboration } \\
\text { 2. Student as researcher } \\
\text { 2. Blended learning } \\
\text { 3. Differentiation } \\
\text { 4. Note-taking } \\
\end{array}$ \\
\hline Artifacts & $\begin{array}{l}\text { 1. Grading practices } \\
\text { 2. Use of LMS for blended learning } \\
\text { 3. Note-taking } \\
\text { 4. Project-based learning } \\
\text { 4. Student as researcher }\end{array}$ \\
\hline
\end{tabular}


CENTERED $21^{\text {ST }}$ CENTURY CLASSROOMS

Table 11: Common Themes from Pre- and Post-surveys

\begin{tabular}{|c|c|c|c|}
\hline \multicolumn{2}{|c|}{ Pre-Survey Fall 2010} & \multicolumn{2}{|l|}{ Post-Survey, Spring 2012} \\
\hline Response Theme & Frequency & Response Theme & Frequency \\
\hline Student engagement & 20 & Technical difficulties & 17 \\
\hline Teacher as facilitator & 15 & Differentiation & 14 \\
\hline Student-student collaboration & 10 & Student as researcher & 13 \\
\hline Student as researcher & 9 & Student engagement & 11 \\
\hline Differentiation & 8 & Use of LMS for blended learning & 10 \\
\hline Note-taking & 7 & Grading practices & 4 \\
\hline Student ownership of learning & 7 & Lesson planning & 4 \\
\hline Inequity & 6 & Student as teacher & 4 \\
\hline No change will occur & 6 & Student-student collaboration & 4 \\
\hline Project-based learning & 6 & Teacher as facilitator & 4 \\
\hline Student responsibility & 6 & Depth of student learning & 3 \\
\hline Problem-solving & 5 & Finding new resources (time) & 3 \\
\hline Depth of student learning & 4 & Project-based learning & 3 \\
\hline Multi-disciplinary learning & 4 & Real-world applications & 3 \\
\hline Finding new resources (time) & 4 & Student ownership of learning & 3 \\
\hline Student isolation & 3 & Higher student achievement & 2 \\
\hline Teacher buy-in & 3 & Lack of student computer skills & 2 \\
\hline Teacher-teacher collab. (time) & 3 & Necessity of a back-up plan & 2 \\
\hline Textbook resources & 3 & Teacher flexibility & 2 \\
\hline Grading practices & 2 & Procedures & 1 \\
\hline Increased teacher workload & 2 & Reteach & 1 \\
\hline Lesson planning & 2 & Teacher-teacher collab. (time) & 1 \\
\hline Real-world applications & 2 & & \\
\hline Technology dependent & 2 & & \\
\hline Lack of teacher control & 1 & & \\
\hline Logistical concerns & 1 & & \\
\hline Pressure to improve & 1 & & \\
\hline Procedures & 1 & & \\
\hline Reteach & 1 & & \\
\hline Special education & 1 & & \\
\hline Student as teacher & 1 & & \\
\hline Time & 1 & & \\
\hline
\end{tabular}


CENTERED $21^{\text {ST }}$ CENTURY CLASSROOMS

Table 12: Common Themes from Teacher Interviews

\begin{tabular}{|c|c|c|c|}
\hline \multicolumn{2}{|l|}{ Interviews Spring 2011} & \multicolumn{2}{|l|}{ Interviews Spring 2012} \\
\hline Response Theme & Frequency & Response Theme & Frequency \\
\hline Student engagement & 8 & Finding new resources (time) & 14 \\
\hline Teacher-teacher collab.(time) & 8 & Teacher-teacher collab. (time) & 13 \\
\hline Differentiation & 6 & Procedures & 9 \\
\hline Finding new resources (time) & 6 & Student engagement & 7 \\
\hline Project-based learning & 5 & Teacher as facilitator & 7 \\
\hline Student as teacher & 5 & Differentiation & 5 \\
\hline Procedures & 4 & Specific resource & 5 \\
\hline Teacher flexibility & 4 & Student-student collaboration & 5 \\
\hline Technical difficulties & 4 & Logistical concerns & 4 \\
\hline Depth of student learning & 3 & Pressure to improve & 4 \\
\hline Grading practices & 3 & Technical difficulties & 4 \\
\hline Lesson planning & 3 & Use of LMS for blended learning & 4 \\
\hline Real-world applications & 3 & Monitoring & 3 \\
\hline Student as researcher & 3 & Student as researcher & 3 \\
\hline Higher student achievement & 2 & Student as teacher & 3 \\
\hline Laptop available at all times & 2 & Outside professional development & 2 \\
\hline Logistical concerns & 2 & Reteach & 2 \\
\hline Multi-disciplinary learning & 2 & Special education & 2 \\
\hline Reteach & 2 & Time management & 2 \\
\hline Student ownership of learning & 2 & Classroom flipping & 1 \\
\hline Student-student collaboration & 2 & Grading practices & 1 \\
\hline Use of LMS for blended learning & 2 & Informal PD & 1 \\
\hline Classroom flipping & 1 & Lack of use in math class & 1 \\
\hline Necessity of a back-up plan & 1 & Necessity of a back-up plan & 1 \\
\hline Noise level & 1 & Noise level & 1 \\
\hline Outside professional development & 1 & PD with content area & 1 \\
\hline Special education & 1 & Project-based learning & 1 \\
\hline Specific resource & 1 & Student achievement & 1 \\
\hline Student as teacher & 1 & Student as behavior manager & 1 \\
\hline Student as behavior manager & 1 & & \\
\hline Student learning styles & 1 & & \\
\hline
\end{tabular}


CENTERED $21^{\text {ST }}$ CENTURY CLASSROOMS

Table 13: Common Themes from Learner Management System

\begin{tabular}{|c|c|c|c|}
\hline \multicolumn{2}{|c|}{ Learner Management System Spring 2011 } & \multicolumn{2}{|c|}{ Learner Management System Spring 2012 } \\
\hline Response Theme & Frequency & Response Theme & Frequency \\
\hline Grading practices & 17 & Grading practices & 18 \\
\hline Note-taking & 10 & Blended learning & 15 \\
\hline Blended learning & 7 & Note-taking & 9 \\
\hline Project-based learning & 5 & Project-based learning & 6 \\
\hline Differentiation & 1 & Student as researcher & 6 \\
\hline Student as researcher & 1 & Student-student collaboration & 4 \\
\hline Student-student collaboration & 1 & Student responsibility & 2 \\
\hline Textbook resources & 1 & Textbook resources & 2 \\
\hline & & Differentiation & 1 \\
\hline & & Policies & 1 \\
\hline
\end{tabular}




\section{Chapter V - Discussion}

\section{Professional Development for Transforming Classrooms}

The purpose of this study was to determine the appropriate professional development and design process necessary to transform traditional classrooms into student-centered $21^{\text {st }}$ century classrooms. While the study was conducted utilizing a design-based action research model in which needs assessments and evaluation was done in a cyclic fashion to better inform decisions, when viewed as a single study, recurring themes emerge across all research cycles. For this particular staff, four components of professional development yielded the greatest response: collaboration, modeling, exploration, and choice.

Collaboration. Without question, collaboration was the key to successful transformation at this school. Teachers were given ample opportunity to share through daily team meetings, regular professional development sessions, and informal discussions. Teachers utilized one another to gain knowledge and vent frustrations both before and after implementation of one-toone computing. Whether the collaboration was done in a structured environment or an informal one, teachers sought out suggestions and solutions. Knowing that other teachers in the building were going through the same transition or had recently transformed their classroom, created a sense of comradery, which allowed for ease in collaboration. As noted in the review of literature, collective participation is a necessary component of professional development. The participants in this study concurred with the findings of Garet, Porter, Desimone, Birman, and Yoon (2001) in citing peer collaboration as a factor for success.

Modeling. In the same way that having others transitioning in the same building provided someone with whom to discuss issues, having someone one else in the same building transitioning their classroom provided the opportunity to see it in action. Similar to the findings 
of Brand (1998), noted earlier in the review of literature, teachers in this study who expressed discomfort over changing their teaching styles became much more at ease once they were able to see the results in other classrooms. The school's phased-in approach to classroom laptop implementation assisted greatly in this regard. By allowing a small group of teachers to take the lead and then adding additional classroom teachers each semester, those not selected to be among the first cohort to change had the opportunity to learn from their predecessors.

Exploration. Providing time for teachers to be exposed to new ideas and resources is a necessary component to facilitating change in instruction. However, exposure is not enough. Exploration of resources should be done hand-in-hand with collaboration. Teachers need to have the opportunity to discuss how they can utilize new resources within their curriculum and teaching methods. Teachers can benefit from discussion among instructors who are teaching the same grade or those who are teaching the same content. No matter the manner in which the exploration occurs, it should be done in regards to how to best utilize new tools and ideas in the existing curriculum.

Choice. In this study, teachers benefitted from having many resources from which to choose. When choices were limited, teachers were forced to select the same tools, stifling classroom creativity, creating learner burnout, and not allowing for real-world problem-solving. Once teachers had a robust "toolbox" from which to select resources, they began sharing multiple resources with students, and eventually allowing students to choose the best tool for each task. Providing teachers with many resource options meant students were given the opportunity to embrace $21^{\text {st }}$ century skills. 
In her interview at the end of the second year, Ms. Patel described the importance of all four of these components on her professional development during the two-year implementation cycle:

The most helpful thing, I think, was from (Mrs. Scott) and (Mrs. Cooper) because they had gotten their feet wet. They were the experimental guinea pigs. So when I was not sure how to do this or that, I would go to them "How do you do this? How do you do that?" Talking with other teachers about how things worked, that helped a lot.

Oh, that time we were in (Mrs. Todd)'s room, and we had a chance to just go through that plethora of sites. You know, "Look at this. Look at that. That's what you need." You need time to experiment and plus somebody there as a guide, "Go here. Go there. Try this. Try that." That was very helpful and I used a lot of things that popped up there. At the time I thought, well, even if I don't know how to use that, I had a handle on it so that I could explore it a little bit more. That time to be able to explore is priceless. Time to explore in a group. Plus it was another one of those things where someone said "Try such and such site." or "So and so, I know you do a unit on this." or "You teach that, this is something you can use." Having other teachers in that room at the same time was really helpful.

\section{Design-Based Action Research}

The design-based action research structure of this study greatly supported the learning of the teachers. Teachers benefited from fact that professional development sessions were planned and selected based on an instructional design model of needs assessment, design, implementation, and evaluation. By analyzing an initial needs assessment and evaluating the implementation in four cycles across two years, the professional development sessions were able 
to be tailored to the needs of this particular staff. As noted in the review of literature, Opfer and Pedder (2011) pointed out that the professional activities that work with one staff will not necessarily work with a different staff. Through the utilization of the instructional design model, successful professional development for this staff was able to be determined and improved upon.

\section{Limitations}

This study was limited to one middle school with teachers who had already expressed an interest in transitioning their traditional classrooms to $21^{\text {st }}$ century classrooms; for this staff, the "buy-in" was already present. As stated, future initiatives may be able to circumvent this limitation by completing a needs assessment prior to implementation and establishing clear goals throughout the building. Utilizing the cyclical instructional design model of needs assessment, design, implementation, and evaluation may also assist in ensuring professional development sessions fully meet the needs of the unique staff. A diagram of the proposed instructional design model can be seen in figure 1.

Additionally, the thoughts of the assistant principal in this study should not be completely overlooked. Her concern that middle school students were provided instruction using constructivist strategies, but would be expected to learn via traditional methods in high school may have merit. Research on student flexibility in classrooms of varied teaching methods may be an area for future study.

\section{Implications for Policy}

As schools, school districts, and states begin to transition to one-to-one computing to better enable the delivery of $21^{\text {st }}$ century skills, it is tempting to think that providing laptops to every student will create environments where such skills will thrive. Hardware alone cannot provide students with the skills necessary for the future. Teachers must be provided with the 
professional development necessary to effectively transition their teaching practices to environments which nurture student problem-solving, cooperation, and higher level thinking.

In addition to the necessity of professional development, this study indicates that large scale initiatives should be completed in design phases for optimal success. The instructional design model utilized in this study, a cyclical model of needs assessment, design, implementation, and evaluation, may allow implementation to be tailored to the specific needs of a school's staff (see figure 1). While it may be tempting to create a "one-size-fits-all" professional development plan for a school, school-district, or state, the varied needs of each school staff can be considered and met through the use of this instructional design model, while still meeting the large-scale goals of the state or school district.

Finally, as suggested by Muir-Herzig (2004) and Brand (1998), the availability of an onsite Technology Integration Specialist (TIS) was instrumental in offering professional development and support to the staff as they transitioned their teaching methodologies. The school-level TIS in this study was able to utilize the instructional design model to effectively tailor the professional development to the needs of the school staff. Providing support personnel to design, implement, and evaluate professional development is a necessary aspect of transitioning traditional classrooms to $21^{\text {st }}$ century classrooms.

\section{Discussion Summary}

For the school participating in this study, the developmental cycle allowed professional development to be tailored across four semesters to meet the teachers' needs. Specifically, this study found that those needs included time for collaboration, opportunities to explore resources, choices for instructional delivery, and a phased-in approach which allowed modeling to occur. 
When transitioning from traditional classrooms to $21^{\text {st }}$ century classrooms, the needs of each staff will be unique. Utilizing a cyclical instructional design model of needs assessment, design, implementation, and evaluation allows the needs of each staff to fully inform the professional development sessions. 


\section{References}

Apple Inc. (2008). Apple classrooms of tomorrow-today: Learning in the $21^{\text {st }}$ century.

Retrieved from http://ali.apple.com/acot2/global/files/ACOT2_Background.pdf

Andrews, D. H., \& Goodson, L. A. (1980). A comparative analysis of models of instructional design. Journal of Instructional Development, 3(4), 2-16. doi: 10.1007/BF02904348

Armstrong, S., \& Warlick, D. (2004). The new literacy. Retrieved from Tech Learning website: http://www.techlearning.com/story/showArticle.jhtml?articleID=47102021

Barab, S., \& Squire, K. (2004). Design-based research: Putting a stake in the ground. Journal of the Learning Sciences, 13(1), 1-14. doi: 10.1207/s15327809j1s1301_1

Becker, H. J. (1994). How exemplary computer-using teachers differ from other teachers: implications for realizing the potential of computers in schools. Journal of Research on Computing in Education, 26(3), 291-322. doi: 10.1080/08886504.1994.10782093

Bell, S. (2010). Project-based learning for the 21st century: Skills for the future. Clearing House, 83(2), 39-43. doi:10.1080/00098650903505415

Brand, G. A. (1998). What research says: Training teachers for using technology. Journal of Staff Development, 19, 10-13. Retrieved http://wikieducator.org

Brown, A. L. (1992). Design experiments: Theoretical and methodological challenges in creating complex interventions in classroom settings. The Journal of the Learning Sciences, 2(2), 141-178. Retrieved from http://www.jstor.org/stable/1466837

Cobb, P., Confrey, J., Lehrer, R., \& Schauble, L. (2003). Design experiments in educational research. Educational Researcher, 32(1), 9-13. Retrieved from http://designbasedresearch.org 
Collins, A., Joseph, D., \& Bielaczyc, K. (2004). Design research: Theoretical and methodological issues. Journal of the Learning Sciences, 13(1), 15-42. Retrieved from http://isites.harvard.edu/fs/docs/icb.topic122288.files/Collins.pdf

de Vries, S., Jansen, E. P. W. A., \& van de Grift, W. J. C. M. (2013). Profiling teachers' continuing professional development and the relation with their beliefs about learning and teaching. Teaching and Teacher Education, 33(0), 78-89. doi: 10.1016/j.tate.2013.02.006

de Vries, S., van de Grift, W. J. C. M., \& Jansen, E. P. W. A. (2013). Teachers' beliefs and continuing professional development. Journal of Educational Administration, 51(2), 213231. Retrieved from http://www.emeraldinsight.com/0957-8234.htm

Design-Based Research Collective. (2003). Design-based research: An emerging paradigm for educational inquiry. Educational Researcher, 32(1), 5-8. Retrieved from http://designbasedresearch.org

Desimone, L. M., Porter, A. C., Garet, M. S., Yoon, K. S., \& Birman, B. F. (2002). Effects of professional development on teachers' instruction: Results from a three-year longitudinal study. Educational Evaluation and Policy Analysis, 24(2), 81-112. Retrieved from http://www.jstor.org/stable/3594138

Donovan, L., Hartley, K., \& Strudler, N. (2007). Teacher concerns during initial implementation of a one-to-one laptop initiative at the middle school level. Journal of Research on Technology in Education (International Society for Technology in Education), 39(3), 263286. Retrieved from http://iste.org

Dunleavy, M., Dexter, S., \& Heinecke, W. F. (2007). What added value does a 1:1 student to laptop ratio bring to technology-supported teaching and learning? Journal of Computer Assisted Learning, 23(5), 440-452. doi:10.1111/j.1365-2729.2007.00227.x 
Dwyer, D. (1994). Apple classrooms of tomorrow: What we've learned. Educational Leadership, 51(7), 4-10. Retrieved from http://ascd.org

Dwyer, D. C., Ringstaff, C., \& Sandholtz J.H. (1990). Teacher beliefs and practices part I: Patterns of change: The evolution of teachers' instructional beliefs and practices in highaccess-to-technology classrooms first-fourth year findings (Report No. 8). Retrieved from Apple Inc. website: http://www.apple.com/euro/pdfs/acotlibrary/rpt8.pdf

Dwyer, D. C., Ringstaff, C., \& Sandholtz J.H. (1990). Teacher beliefs and practices part II: Support for change: The evolution of teachers' instructional beliefs and practices in highaccess-to-technology classrooms first-fourth year findings (Report No. 9). Retrieved from Apple Inc. website: http://www.apple.com/euro/pdfs/acotlibrary/rpt9.pdf

Fox, M. (2006). Bridging the digital divide: The impact of laptop computer initiatives on middle school teaching and learning. International Journal of Learning, 13(5), 44-55. Retrieved from http://ijl.cgpublisher.com

Garet, M. S., Porter, A. C., Desimone, L., Birman, B. F., \& Yoon, K. S. (2001). What makes professional development effective? Results from a national sample of teachers. American Educational Research Journal, 38(4), 915-945. Retrieved from http://www.jstor.org/stable/3202507

Kose, B., \& Lim, E. (2011). Transformative professional learning within schools: Relationship to teachers' beliefs, expertise and teaching. Urban Review, 43(2), 196-216. doi:10.1007/s11256-010-0155-9

Lawless, K. A., \& Pellegrino, J. W. (2007). Professional development in integrating technology into teaching and learning: Knowns, unknowns, and ways to pursue better questions and answers. Review of Educational Research, 77(4), 575-614. doi:10.3102/0034654307309921 
Levine, T. H., \& Marcus, A. S. (2010). How the structure and focus of teachers' collaborative activities facilitate and constrain teacher learning. Teaching \& Teacher Education, 26(3), 389-398. doi:10.1016/j.tate.2009.03.001

Muir-Herzig, R. (2004). Technology and its impact in the classroom. Computers \& Education, 42(2), 111-131. doi:10.1016/S0360-1315(03)00067-8

Mullins, K. (2014). Good IDEA: Instructional design model for integrating information literacy. The Journal of Academic Librarianship, 40(3-4), 339-349. doi: 10.1016/j.acalib.2014.04.012

North Central Regional Educational Laboratory. (2003). enGauge $21^{\text {st }}$ century skills: Literacy in the digital age. Retrieved from http://www.ncrel.org/engauge/skills/engauge21st.pdf

Opfer, V. D., \& Pedder, D. (2011). Conceptualizing teacher professional learning. Review of Educational Research, 81(3), 376-407. doi:10.3102/0034654311413609

Partnership for $21^{\text {st }}$ Century Skills. (2003). Learning for the $21^{\text {st }}$ century: A report and MILE guide for $21^{\text {st }}$ century skills. Retrieved from http://21stcenturyskills.org/images/stories/ otherdocs/p21up_Report.pdf

Partnership for $21^{\text {st }}$ Century Skills (2006). Results that matter: $21^{\text {st }}$ century skills and high school reform. Retrieved from http://21stcenturyskills. org/documents/RTM2006.pdf.

Pecore, J. L. (2013). Beyond beliefs: Teachers adapting problem-based learning to preexisting systems of practice. Interdisciplinary Journal of Problem-Based Learning, 7(2), 6-33. doi:10.7771/1541-5015.1359

Reeves, T.C. (2006). Design research from a technology perspective. In J. van den Akker, K. Gravemeijer, S. McKenney, \& N. Nieveen (Eds.), Educational design research (pp. 86109). London: Routledge. 
Reeves, T. C. (2000, April). Enhancing the worth of instructional technology research through “design experiments” and other development research strategies. In SIG/Instructional Technology (Sponsor), International perspectives on instructional technology research for the $21^{\text {st }}$ century. Symposium conducted at the meeting of the American Educational Research, New Orleans, LA.

Richey, R. C., Klein, J. D., \& Nelson, W. A. (2004). Developmental research: Studies of instructional design and development. In D. Johassen (Ed.), Handbook of research on educational communications and technology (2 ${ }^{\text {nd }}$ ed., pp. 1099-1130). Taylor \& Francis.

Salpeter, J. (2003). 21 $21^{\text {st }}$ century skills: Will our students be prepared? Retrieved from Tech Learning website: http://www.techlearning.com/story/showArticle.jhtml?articleID= 15202090

Simms, J., \& Knowlton, D. S. (2008). Ideas in practice: Instructional design and delivery for adult learners. Journal of Developmental Education, 32(1), 20-30.

TED (Producer), \& Mitra, S. (Presenter). (2010). The child-driven education [Digital video]. Available from http://www.ted.com/talks/sugata_mitra_the_child_driven_education\# van den Akker, J. (1999). Principles and methods of development research. In J. van den Akker, R.M. Branch, K. Gustafson, N. Nieveen, \& T. Plomp (Eds.), Design approaches and tools in education and training (pp. 1-14). doi: 10.1007/978-94-011-4255-7_1 van den Akker, J., Gravemeijer, K., McKenney, S., \& Nieveen, N. (2006). Introducing educational design research. In J. van den Akker, K. Gravemeijer, S. McKenney, \& N. Nieveen (Eds.), Educational design research (pp. 3-7). London: Routledge. 
Running head: TRANSFORMING TRADITIONAL CLASSROOMS INTO STUDENT- 66 CENTERED $21^{\text {ST }}$ CENTURY CLASSROOMS

Wang, F., \& Hannafin, M. J. (2005). Design-based research and technology-enhanced learning environments. Educational Technology Research \& Development, 53(4), 5-23. Retrieved from http://www.jstor.org/stable/30221206

Windschitl, M., \& Sahl, K. (2002). Tracing teachers' use of technology in a laptop computer school: The interplay of teacher beliefs, social dynamics, and institutional culture. American Educational Research Journal, 39(1), 165-205. Retrieved from http://jstor.org/stable/3202475 


\section{Appendices}

\section{Appendix A: Data Sources}

\begin{tabular}{|c|c|c|c|}
\hline Data source & Purpose & Data collection procedures & Data analysis procedures \\
\hline $\begin{array}{l}\text { Teacher } \\
\text { surveys }\end{array}$ & $\begin{array}{l}\text { used to shape and } \\
\text { guide changes in } \\
\text { professional } \\
\text { development } \\
\text { content and } \\
\text { delivery methods }\end{array}$ & $\begin{array}{l}\text { electronic surveys through } \\
\text { the school's learner } \\
\text { management system } \\
\text { (Edline) }\end{array}$ & $\begin{array}{l}\text { surveys were exported to } \\
\text { an Excel file, saved by } \\
\text { date, and analyzed for } \\
\text { recurring themes }\end{array}$ \\
\hline $\begin{array}{l}\text { Teacher, } \\
\text { administrator, } \\
\& \text { technology } \\
\text { staff } \\
\text { interviews }\end{array}$ & $\begin{array}{l}\text { used to shape and } \\
\text { guide changes in } \\
\text { professional } \\
\text { development } \\
\text { content and } \\
\text { delivery methods }\end{array}$ & $\begin{array}{l}\text { audio recorded interviews } \\
\text { and informal discussions } \\
\text { with the school's } \\
\text { instructors, administrators, } \\
\text { and technology staff }\end{array}$ & $\begin{array}{l}\text { interview transcripts were } \\
\text { analyzed for recurring } \\
\text { themes }\end{array}$ \\
\hline $\begin{array}{l}\text { Classroom } \\
\text { observations }\end{array}$ & $\begin{array}{l}\text { conducted in an } \\
\text { attempt to gain } \\
\text { greater } \\
\text { understanding of } \\
\text { the outcomes }\end{array}$ & $\begin{array}{l}\text { direct observation of } \\
\text { classroom structure and } \\
\text { management; anecdotal } \\
\text { observations were gathered } \\
\text { from instructors }\end{array}$ & $\begin{array}{l}\text { observation notes were } \\
\text { analyzed for recurring } \\
\text { themes }\end{array}$ \\
\hline $\begin{array}{l}\text { Teacher } \\
\text { discussion and } \\
\text { focus groups }\end{array}$ & $\begin{array}{l}\text { used to shape and } \\
\text { guide changes in } \\
\text { professional } \\
\text { development } \\
\text { content and } \\
\text { delivery methods }\end{array}$ & $\begin{array}{l}\text { group discussions directly } \\
\text { observed by researcher or } \\
\text { reported on by members of } \\
\text { the focus group }\end{array}$ & $\begin{array}{l}\text { discussion notes were } \\
\text { analyzed for recurring } \\
\text { themes across all groups }\end{array}$ \\
\hline Artifacts & $\begin{array}{l}\text { collected and } \\
\text { analyzed for their } \\
\text { effectiveness }\end{array}$ & $\begin{array}{l}\text { teacher lesson plans, posts } \\
\text { to learner management } \\
\text { system (Edline), graphic } \\
\text { organizers to assist } \\
\text { classroom transformation, } \\
\text { professional development } \\
\text { agendas and handouts, } \\
\text { school and classroom } \\
\text { policies }\end{array}$ & $\begin{array}{l}\text { artifacts were analyzed for } \\
\text { need, change over time, } \\
\text { organization techniques, } \\
\text { and other themes may } \\
\text { have manifested }\end{array}$ \\
\hline
\end{tabular}




\section{Appendix B: Sample from Teacher Surveys}

Teacher surveys were completed in the fall of 2010 and the spring of 2012. The initial survey served as the school's needs assessment. Surveys were distributed and collected electronically. Completed surveys were exported to an Excel spreadsheet. Teacher responses were analyzed for recurring themes. Such themes were noted using Microsoft's comment feature and tallied for frequency.

The sample below indicates the question, teacher responses, and coding used for teacher surveys completed in the fall of 2010. 
Running head: TRANSFORMING TRADITIONAL CLASSROOMS INTO STUDENTCENTERED $21^{\text {ST }}$ CENTURY CLASSROOMS

\begin{tabular}{|c|c|c|}
\hline $\begin{array}{c}\text { Submitter } \\
\text { ID }\end{array}$ & How do you foresee the laptops being used in your classroom? & \\
\hline 1 & $\begin{array}{l}\text { Hopefully we will be able to access the book website buhen having trouble with certain } \\
\text { Also, I hope to be able to have the daily notes fight in front of the stu }\end{array}$ & Comment [M1]: Textbook resources \\
\hline \multirow[b]{2}{*}{2} & Researching back ground information at be beginning of a unit and when completin & Comment [M2]: Note-taking \\
\hline & Students can access copies of my notes, keep thier notes and a journal $\log$ in their student folders & Comment [M3]: Student as researcher \\
\hline \multirow[b]{2}{*}{3} & Laptops in the classroom would be used for project based learning in my classroom I would hope for lifferent outcomes from different groups of & Comment [M4]: Note-taking \\
\hline & $\begin{array}{l}\text { students pecause they were being given a problem to solve yet several different resources to use yet all would come to understanding our world } \\
\text { better because of it. Much more could be done with computer access for each student. }\end{array}$ & Comment [M5]: Project-based learning \\
\hline \multirow{3}{*}{4} & Many of my lpecial education students have trouble keeping their attention on task. I hope that with the use of the computers, they will be able to & Comment [M6]: Differentiation \\
\hline & focus on their own learning / instruction rather than those of others Another weakness for my sp. ed. students includes abtract thought. I am hopeful & Comment [M7]: Special Education students \\
\hline & that using the computers as a tool will create a more concrete/visual learning envionment. & Comment [M8]: Student ownership of learning \\
\hline 5 & I see the laptops as being used to help my students visually see how a problem is being worked out for them. & \\
\hline 6 & I foresee group work, kesearch and brojet-based learning I see the peacher as the facilitator, not as the moving mouth the entire period. & Comment [M9]: Student as researcher \\
\hline \multirow{3}{*}{7} & $\begin{array}{c}\text { For story publication } \\
\text { juformation gathering and searching (research) }\end{array}$ & Comment [M10]: Project-based learning \\
\hline & web site games/reinforcement activities & Comment [M11]: Teacher as facilitator \\
\hline & $\begin{array}{c}\text { blogs } \\
\text { shared story writing } \\
\text { evaluating written materials/debates }\end{array}$ & Comment [M12]: Student as researcher \\
\hline \multirow{2}{*}{8} & $\begin{array}{l}\text { I see my laptops in my classroom being used as a way for students to self-leann and go at their own pace. Once of the problems I'm finding is that } \\
\text { one class has an assortment of learners at different levels. My hope is to use my laptops in a way that will allow my students to progress at their own }\end{array}$ & Comment [M13]: Differentiation \\
\hline & $\begin{array}{l}\text { pace and see a more substantial improvement. I would facilitate the room and allow students to probelm-solve for themselves with my guidance and } \\
\text { support. }\end{array}$ & Comment [M14]: Teacher as facilitator \\
\hline 9 & Students will have the opportunity to complete & \\
\hline & assiguments, research and problem solving activities that are specifically designed to meet individual ability levels. & Comment [M15]: Student as researcher \\
\hline 10 & Students will recieve problems, such as a food borne illness and can as individuals or small groups kesearch the types of illnesses. & Comment [M16]: Problem-solving \\
\hline 11 & $\begin{array}{l}\text { I see a student-centered classroom. Teacher is facilitator and NOT the "giver of ALI knowledget. I ffel 1:1 is the best place for "discovery" } \\
\text { learning to take place which is what scieace is all about. I see more student-centered communication ....and the teacher circulating around the }\end{array}$ & Comment [M17]: Differentiation \\
\hline & $\begin{array}{l}\text { classroom touching base with students and helping when needed but otherwise the prudents are "in charge". } \\
\end{array}$ & Comment [M18]: Student as researcher \\
\hline \multirow{3}{*}{12} & I. I would like to see students able to work on the computer to solve in-class problems and then show/explain solutions on the whiteboard, without & Comment [M19]: Teacher as facilitator \\
\hline & $\begin{array}{l}\text { leaving their seats. } \\
\text { a. laptops commected to whiteboard } \\
\text { b. } 4 \text { mobile presenters around room } \\
\text { c. a way to use math symbols w/o } \\
\text { having to use equation editor }\end{array}$ & Comment [M20]: Student ownership of learning \\
\hline & $\begin{array}{l}\text { II Problem solving projects for group work once or twice a week } \\
\text { III Competition type sites/problems/games }\end{array}$ & Comment [M21]: Problem-zolving \\
\hline 13 & I plan to use my laptops in a PBL situations that are kross-curriculart I want to become the facilitator of knowledget & Comment [M22]: Project-bazed learning \\
\hline 14 & $\begin{array}{l}\text { As tools for learning. As doors to other experiences. As devices to extend literacy. I could go on and on with various metaphors/similies for } \\
\text { laptops in the classroom. }\end{array}$ & Comment [M23]: Multi-disciplinary learning \\
\hline 15 & access online textbook and extra features online that come with the textbook. projects & Comment [M24]: Teacher as facilitator \\
\hline 16 & I can see the students kaking notes bn them, lioing researchl creating projects, making videos, and learning les son interactively. & Comment [M25]: Textbook resources \\
\hline \multirow{2}{*}{17} & One way that laptops can be used in my classroom is for interactive websites that I project on my Intelliboard. Students can perform the activity on & Comment [M26]: Note-taking \\
\hline & their personal laptops instead of using time to let students take turns on the Intelliboard. & Comment [M27]: Student as researcher \\
\hline 18 & I hope to implement project based lessons bhat will be assisted with the use of the laptop. & Comment [M28]: Project-based learning \\
\hline \multirow[t]{2}{*}{19} & $\begin{array}{l}\text { ENGLISH CLASS: ALL WRITING WILL BE CONVERTED FROM PAPER PENCIL TO COMPUTER. } \\
\text { SOC STUDIES: GUIDES, NOTES COMPLETED WITHOUT PAPER } \\
\text { POWER PONTS, WHITE BOARD MATERLALS PUT ON LAP TOPS AS WELL AS PROJECTED ON WALL }\end{array}$ & Comment [M29]: Note-taking \\
\hline & & \\
\hline \multirow{5}{*}{20} & \multirow{5}{*}{$\begin{array}{l}\text { The subject that you teach will have an impact on how to utilize the laptops in the classroom. } \\
\text { For Math-Having the accessbility to hote taking Is a must! I would use the laptops as a note taking tool. Notes could be saved and easily recovered } \\
\text { Accessing textbooks online as well as utilizing powerpoints to Feteach critical skills laily during independent practice would be helpful. Other } \\
\text { possibilities would include educational math sites that would enhance mathematical skills. Ex. Right now many 6th graders don't know } \\
\text { multiplication tables. Timed quizes online may belp in this situation. } \\
\text { English/Language Arts- How wonderful to access WV Writes, Plato and similar sites in the classroom as compared to traveling to a lab. } \\
\text { Keeping a daily writing journal would enhance keyboarding skills for the Writing Assessment. }\end{array}$} & \\
\hline & & Comment [M30]: Note-taking \\
\hline & & Comment [M31]: Textbook resources \\
\hline & & Comment [M32]: Reteach \\
\hline & & \\
\hline 21 & I can see the laptops being used in various writing activities and with projects, but not necessarily as a tool that will be used on a daily bases. & \\
\hline
\end{tabular}




\section{CENTERED $21^{\text {ST }}$ CENTURY CLASSROOMS}

\begin{tabular}{|c|c|}
\hline Submitter ID & What will be the impact on teachers' instructional practices? \\
\hline 1 & $\begin{array}{l}\text { I will definitely have to change my way of teaching from whole class instruction with some individual class participation to the majority of } \\
\text { findividual class participation| }\end{array}$ \\
\hline 2 & $\begin{array}{l}\text { When completing lab activites, I frequently include a paragraph in the lab instructions providing background inforamtion, with laptops, the } \\
\text { students could quickly do their own Fesearch and discuss what they have discovered about the topic of the lab. }\end{array}$ \\
\hline 3 & $\begin{array}{l}\text { Teacher as facilitator has always been a standard. Instructional practices would now have to include a better teacher knowledge base of } \\
\text { technology and a wrllinguess to be a coutimual learner| }\end{array}$ \\
\hline 4 & $\begin{array}{l}\text { As we are introduced to a new way of teaching, we will kely on eachother for advice/guidance/suggestions for best instructional practices Well } \\
\text { all be in the same boat, so we must be able to try something new and report back to others what has worked and what has not worked. }\end{array}$ \\
\hline 5 & $\begin{array}{l}\text { It will make it easier for me if a student misses a day of notes because it will be easy to } 2 \text {-mail them the notes at the start of class so they are not } \\
\text { behind the rest of the class. }\end{array}$ \\
\hline 6 & $\begin{array}{l}\text { I feel that my instructional practices will need to be adjusted quite a bit in order to incorporate the laptops into my classroom. Some things will } \\
\text { remain the same, but I believe that my plaming will be more focused on discovery learning and letting the |students have more freedom to "rum } \\
\text { with the content" }\end{array}$ \\
\hline 7 & $\begin{array}{l}\text { to reinforce or enrichment classroom CSO's and not to add to the workload (to enhance)I want it to truly benefit the lesson and not just do } \\
\text { something to do it. }\end{array}$ \\
\hline 8 & $\begin{array}{l}\text { Instructional practices will need to be more project and problem solving-based | Teachers will not lecture and students take notes off a } \\
\text { PowerPoint; studeats will have more opportunities to learn how to use technology in a way that supports their learning. }\end{array}$ \\
\hline 9 & There will be less lecture teacher directed instruction and more student learner based self-paced instruction \\
\hline 10 & More student hands-on experiences, and less teacher talking \\
\hline 11 & $\begin{array}{l}\text { Teacher instructional practices will ahve to become more student-centered and teachers will ahve to be willing to give up control of their } \\
\text { classroom and to open up to making mistakes. We all can lean from our mistakes...teachers and students alike. }\end{array}$ \\
\hline & $\begin{array}{l}\text { Since Ive always had students actively involved in every lesson, Im not sure how that would change. My goal would still be to be the } \\
\text { facilitator rather than the "giver of all knowledge'|' By the way, this is not new educational psycho-babble. I have articles that I wrote a5-20 }\end{array}$ \\
\hline 12 & $\begin{array}{l}\text { years ago using the same words. } \\
\text { It will definitely be more time consuming for me to be sure that students are not only doing problem solving, but also continue to build their } \\
\text { toolbox of tools/skills. }\end{array}$ \\
\hline 13 & $\begin{array}{l}\text { The use of laptops will khange the role of the teacher in the classroom land thus change instructional practices that will best meet the needs of } \\
\text { the students. }\end{array}$ \\
\hline 14 & $\begin{array}{l}\text { It will greatly change the way I plan and facilitate learning, now that access will be at student finger tips I will now be able to plan more active } \\
\text { leaming experiences for my students, which will naturally lepend upon more collaborationa and problem solving: |Opportunties for student and } \\
\text { teacher collaboration are endless and have yet to be dreamed }\end{array}$ \\
\hline 15 & less direct instruction / more responsibility on students \\
\hline 16 & $\begin{array}{l}\text { My instructional practices would not change overnight. I would start slow and add new items or change parts of lessons as I would go. I would } \\
\text { find what works and what does not work and make the changes. }\end{array}$ \\
\hline 17 & $\begin{array}{l}\text { I manipulate technology in alot of my teaching already, so I believe I will be able to incorporate laptops for my stcuents with ease, pot much } \\
\text { direct impact on my instructional practices. I beleive it will make more time for things to be accomplished in one class session because students } \\
\text { won't be wasting valuable time walking to and from the board. (That time adds up!) }\end{array}$ \\
\hline 18 & $\begin{array}{l}\text { The delivery of the curriculm will be enhanced by opening opportunities for students to leam beyond just paper and pencil and without } \\
\text { limitations within the classroom. }\end{array}$ \\
\hline 19 & I WILL NEED TO SPEND MORE OF MY TIME CHECKING DROP BOX TO GIVE FEEDBACK TO STUDENTS' WORK| \\
\hline 20 & $\begin{array}{c}\text { Teacher's instructional practices would need to be modified at times. Delivery could be the same at times but a more hands/on lesson would be } \\
\text { available using laptops. }\end{array}$ \\
\hline 21 & Given more freedom with the use of technology, but also adding to the demands that are always being added to teachers' jobs. \\
\hline
\end{tabular}

\begin{tabular}{l} 
Comment [M33]: Differentiation \\
Comment [M34]: Student as researcher \\
Comment [M35]: Teacher as facilitator \\
Comment [M36]: Pressure to improve \\
Comment [M37]: Teacher-teacher collaboration \\
Comment [M38]: Note-taking \\
Comment [M39]: Student ownership of learning \\
Comment [M42]: Differentiation \\
Comment [M43]: Teacher as facilitator \\
Comment [M44]: Teacher as facilitator \\
Comment [M45]: No change \\
Comment [M46]: Teacher as facilitator \\
Comment : Project-based learning \\
Comment [M47]: Teacher as faciltator \\
Comment [M48]: Teacher as facilitator \\
Comment [M49]: Student-student collaboration \\
Comment [M50]: Student-teacher collaboration \\
Coment: Student ownership of learning \\
[M54]: Losson planning \\
\hline
\end{tabular}

\begin{tabular}{|c|c|}
\hline $\begin{array}{c}\text { Submitter } \\
\text { ID }\end{array}$ & What will be the impact on the content and rigor of curriculum and instruction? \\
\hline 1 & Hopefully students will be able to grasp concepts better using something they have grown up with and are familiar with. \\
\hline 2 & THe content should be the same, but hopefully we would be able to make it more rigorous and relevant. \\
\hline 3 & Hopefully students will have more time and ample opportumity to participate in more complex skills. \\
\hline 4 & Easy access to the computer at school AND at home will allow students to work with the necessary tools outside of the school setting \\
\hline 5 & It will belp the students understand how to solve harder problems and hopefully make the content more clear to the students. \\
\hline 6 & I think that more content standards will be covered at once, and then within that, will need to be broken down individually (mini lessons, etc.). \\
\hline 7 & to remain true to the CSO's, yet to bring it to Feal life siruations and more relavent to today's student \\
\hline 8 & $\begin{array}{l}\text { I think the content will progress in a way that will enhance every child's learning-as long as they have the ambition to fwork hard and correctly with } \\
\text { this } 1: 1 \text { computing. }\end{array}$ \\
\hline 9 & $\begin{array}{l}\text { There will be an opportunity for mor kross-curricular collaboration with teachers from other } \\
\text { content areas: This will provide students an opportunity to see how practices are utilized in real-world situations; }\end{array}$ \\
\hline 10 & Content and CSO lessons will remain the same. \\
\hline 11 & $\begin{array}{c}\text { 1:1 will make it easier to vcover the content needed because... at least for science...true fintegration of different areas kan take place. Rigor will } \\
\text { definitely increase. }\end{array}$ \\
\hline 12 & $\begin{array}{l}\text { In mathematics, I will monitor closely to be sure that the impact will indeed be positive. My goal would be to keep rigor at a high level and even } \\
\text { |increase in-depth understanding and application }\end{array}$ \\
\hline 13 & $\begin{array}{l}\text { I feel that the content will be impacted greatly and this will allow students to learn to apply, adapt, and interpret information } \mid \text { This in turn will belp } \\
\text { them prepare for a future where their problem solving skills will be greatly needed. }\end{array}$ \\
\hline 14 & $\begin{array}{ll}\text { Rigor will increase. A natural by-product. More big picture and cross-curricular connections } & \text { Extended learning. } \\
\end{array}$ \\
\hline 15 & less rigor for teacher, Ho change in content just delivered differently \\
\hline 16 & $\begin{array}{l}\text { The content would not change but how I deliver the content would I can see the students making the instruction more meaningful them as they } \\
\text { create projects that help each other learn. }\end{array}$ \\
\hline 17 & $\begin{array}{l}\text { The impact on the content would be positive because the students will have so much more access to great resources online. Some students dont have } \\
\text { computers internet at home so this may be their only exposure. Curriculum will be taught in the same way, however, I beleive I will be able to relay } \\
\text { the information easier because each student will be engaged with his/her own laptop father than pulling for their attention to be completely focused } \\
\text { on the Intelliboard for the entire class period. }\end{array}$ \\
\hline 18 & The content rigor will be greater because the students will be completing leanning tasks that require multiple steps to complete. \\
\hline 19 & $\begin{array}{l}\text { STUDENTS WILL BECOME MORE RESPONSIBLE INDIVIDUALLY RATHER THAN "WHOLE CLASS" DYNAMICS. THERE WILL BE } \\
\text { MORE INDEPENDETN WORKING SKILLS NEEDED. RATHER THAN KIDS "VEGGING" OUT IN CLASS. THEY WILL EACH BE } \\
\text { INTERACTIVLY INVOLVED. }\end{array}$ \\
\hline 20 & Content and Curriculum would not change. The CSO's would need to be followed and required skills taught. \\
\hline 21 & expansion of Fesearch based projects \\
\hline
\end{tabular}

\begin{tabular}{l} 
Comment [M57]: Depth of student learning \\
Comment [M58]: Problem-solving \\
Comment [M59]: Real-world applications \\
Comment [M60]: Student responsibility \\
Comment [M61]: Multi-disciplinary learning \\
Comment [M62]: Teacher-teacher collaboration \\
[M64] : No change \\
Comment [M65]: Multi-dicciplinary learning \\
Comment [M66] : Depth of student learning \\
Commenth of student learning \\
[M69]: : Multi-disciplinary learning \\
Comment [M70]: No change \\
Comment [M72]: Student isolation \\
Comment [M73]: No change \\
Comment [M74]: Student as researcher \\
\hline
\end{tabular}


Running head: TRANSFORMING TRADITIONAL CLASSROOMS INTO STUDENT-

\section{CENTERED $21^{\text {ST }}$ CENTURY CLASSROOMS}

\begin{tabular}{|c|c|}
\hline $\begin{array}{l}\text { Submitter } \\
\text { ID }\end{array}$ & What will be the impact on student achievement? \\
\hline 1 & Hopefully the impact will be significant with studeut achievement and understanding Perhaps assessment will be easier. \\
\hline 2 & Hopefully, there will be increase student engagement which should result in higher achievement. \\
\hline 3 & $\begin{array}{l}\begin{array}{l}\text { Students would be better prepared to participate in today's economy and culnure with skills that they acquire. Hopefully achievement would } \\
\text { improve. }\end{array} \\
\end{array}$ \\
\hline 4 & $\begin{array}{l}\text { The consistent availablity of resources frill allow studnets to achieve success in the classroom. They will be working toward an individual goal at } \\
\text { their own pace }\end{array}$ \\
\hline 5 & Hopefully it will help the students understand the content better which will lead to better grades. \\
\hline 6 & $\begin{array}{l}\text { I feel that the students achieve more when we are at the lab, because they are more comfortable with the technology, and are therefore more willing } \\
\text { to complete the lesson activities. }\end{array}$ \\
\hline 7 & $\begin{array}{l}\text { more confidence on the computer } \\
\text { higher achievemet } \\
\text { pasic and more indepth skills conquered. }\end{array}$ \\
\hline 8 & $\begin{array}{l}\text { Hopefully, with this intergration of technology, students will have more of an intrinisc motivation. Perhaps they will become more involved in what } \\
\text { they are learning and pake more leadership in the classrooml. }\end{array}$ \\
\hline 9 & Hopefully, students will have a more personal desire to succeed since they are more in control of their own learning \\
\hline 10 & Students that are skilled in Felf control and self motivation and are fast readers will achieve at a higher levell \\
\hline 11 & Student achievement will increase and I think it will increase much faster than most think it will. \\
\hline 12 & Our students will continue to be successful in math \\
\hline 13 & $\begin{array}{l}\text { The sky is the limit, but essentially we will be preparing for the workplace of the future, one we camnot even fathom at this time. I think we will see } \\
\text { a drop in scores and then a gain after we have our practices in place and allow ourselves some time to change the way we currently teach. }\end{array}$ \\
\hline 14 & It should sore. Barriers should come down and learning should become more active, collaborative, and internalized| \\
\hline 15 & some may struggle, others may shine \\
\hline 16 & $\begin{array}{l}\text { I would think that the student achievement would get better. The students like to use technology and if they are happy at school then hopefully they } \\
\text { will learn more and do better. }\end{array}$ \\
\hline 17 & $\begin{array}{l}\text { Student achievement will increase due to pngaging activities and curriculum that computers providel Students may find educational sites that they } \\
\text { like through the Teacher's curriculum and it's hopeful that they may continue using these sites at home. }\end{array}$ \\
\hline 18 & I think and hope that it will raise because students will be more motivated to complete assiguments with the technology readily available. \\
\hline 19 & MORE 21ST CENTURY SKILLS PREP. \\
\hline 20 & I would hope that student achievement would soar. \\
\hline 21 & $\begin{array}{l}\text { Students will be able to kesearch hnd access information they need, think outside the box in exploring ideas and have the ability to complete task } \\
\text { quicker. Students will become more dependent on technology to function in their everyday lives. } \\
\text { Students will become more dependent on techonology and less able to fumction without it This might not seem so bad, but technology is a thing, not } \\
\text { a mind and if the "thing" is not available the mind needs to be able to retreive infomation. Who is going to build our houses if they can't read the } \\
\text { plans or know if one ' (mark) stands for feet or inches, or other basic facts. You general laborers do not canry or use computers as their tools and we } \\
\text { must have people in that area of our work force. Computers can not replace them. }\end{array}$ \\
\hline
\end{tabular}

Comment [M75]: Grading practices

Comment [M76]: Student engagement

Comment [M77]: New resources Comment [M78]: Differentiation

Comment [M79]: Student engagement

Comment [M80]: Depth of student learning Comment [M81]: Student engagement Comment [M82]: Student ownership of learning Comment [M83]: Student ownership of learning Comment [M84]: Inequity

Comment [M85]: No change

Comment [M86]: Student engagement

Comment [M87]: Student enEagement Comment [M88]: Student engagement

Comment [M89]: Student as researcher Comment [M90]: Technology dependent

Comment [M91]: Student engagement Comment [M92]: Student isolation Comment [M93]: Student engagement Comment [M94]: Inequity

Comment [M95]: Student responsibility Comment [M96]: Student-student collaboration

Comment [M97]: Student engagement Comment [M98]: Student engagement Comment [M99]: Student-student collaboration Comment [M100]: Student-student Comment [M10
collaboration

Comment [M101]: Student engagement

Comment [M102]: Student engagement Comment [M103]: Student as teacher Comment [M104]: Teacher as facilitator Comment [M105]: Student-student collaboration

Comment [M106]: Technology dependent

Comment [M107]: Problem-solving

Comment [M108]: Teacher flexibility

Comment [M109]: Student responsibility Comment [M110]: Student izolation Comment [M111]: Student engagement Comment [M112]: Inequity 

CENTERED $21^{\text {ST }}$ CENTURY CLASSROOMS

\begin{tabular}{|c|c|c|}
\hline $\begin{array}{l}\text { Submitter } \\
\text { ID }\end{array}$ & What will be the impact on your individual classroom culture? & \\
\hline 1 & $\begin{array}{l}\text { I can check findividual performance perhaps more closely by monitoring student progress on the computer. Most students will be more apt to type } \\
\text { answers or opinions rather than write them out. }\end{array}$ & Comment [M113]: Differentiation \\
\hline 2 & $\begin{array}{l}\text { Students will become less dependent on me for the answers } \frac{\text { and realize that they can all contribute. Hopefully, everyone including the quiet ones }}{\text { will find their voice. }}\end{array}$ & Comment [M114]: Teacher as facilitator \\
\hline 3 & Globally expanding in the classroom and cooperating in the classroom also. & Comment [M115]: Student-student \\
\hline 4 & More interactive learning in the resource room. & collaboration \\
\hline 5 & $\begin{array}{l}\text { I think it will connect the students more to one another and they will become more familiar with one another. They will be able to understand each } \\
\text { other better if it is hard to understand someone in the classroom. }\end{array}$ & \\
\hline 6 & $\begin{array}{l}\text { I bope that my individual classroom culture |will reflect a team-like atmosphere where everyone knows that their input is valued | Rules will be even } \\
\text { more important as students take on leadership roles. }\end{array}$ & $\begin{array}{l}\text { Comment [M116]: Student-student } \\
\text { collaboration }\end{array}$ \\
\hline \multirow[t]{2}{*}{7} & \multirow{2}{*}{$\begin{array}{l}\text { positive leaning } \\
\text { hands-on (one-on-one computing) } \\
\text { motivational }\end{array}$} & Comment [M117]: Procedures \\
\hline & & Comment [M118]: Student engagement \\
\hline 8 & $\begin{array}{l}\text { Students will talke more action and leadership roles I I hope to see more engagement from my students, and they will be more attentive to the material } \\
\text { being covered in class. I see students being able to use more of their individual talents to enhance student projects and other instructional activities } \\
\text { with this } 1: 1 \text { computing. }\end{array}$ & $\begin{array}{l}\text { Comment [M119]: Student ownership of } \\
\text { learning }\end{array}$ \\
\hline 9 & Students will be less intimidated to answer questions. & Comment [M120]: Student engagement \\
\hline 10 & Student involvement will take on a new meaning. & Comment [M121]: Differentiation \\
\hline \multirow{2}{*}{11} & \multirow{2}{*}{$\begin{array}{c}\text { My individual classroom culture will become a true global culture with more acceptance of each other and empathy and tolerance for others } \\
\text { increasing }\end{array}$} & Comment [M122]: Student engagement \\
\hline & & Comment [M123]: Student engagement \\
\hline$\frac{12}{13}$ & $\begin{array}{l}\text { Please see number } 1 \text {. } \\
\text { PBL learning with the teacher as a facilitator and the students as leaders. }\end{array}$ & Comment [M124]: Student-student \\
\hline 14 & Addressed in other items. & collaboration \\
\hline 15 & I will use technology more if it is available for my use & Comment [M125]: Project-based learning \\
\hline \multirow[b]{2}{*}{16} & \multirow{2}{*}{$\begin{array}{l}\text { I think the classroom will change as I change. If I am slow to develop lessons bhat incorporate the new technology, the students will be slow to } \\
\text { accept it as part of the classroom. I want my classroom culture to remain similar but have a new flare to it. I can see more computer based projects } \\
\text { and depending on software available, maybe new ways to teach the same old concepts. }\end{array}$} & Comment [M126]: Teacher as facilitator \\
\hline & & Comment [M127]: Lesson planning \\
\hline 17 & $\begin{array}{l}\text { Students will feel very responsible and will feel more "mature" in technology. My classroom will be even more inviting for students because instead } \\
\text { of } 3 \text { PC5, each student will have a laptop they can call "their own." }\end{array}$ & Comment [M128]: Student engagement \\
\hline 18 & I will need to be flexible as well as my students. & Comment [M129]: Teacher flexibility \\
\hline 19 & LESS TEACHER CONTROL OF EVERY MOMENT IN THE CLASS & Comment [M130]: Lack of teacher control \\
\hline 20 & $\begin{array}{l}\text { Continued excitement daily with each new lessond A sense of pride and accomplishment at times when students may take a lead in instruction as } \\
\text { they begin to teach classroom teachers new ways of utilizing the technology in the classroom }\end{array}$ & Comment [M131]: Student engagement \\
\hline 21 & 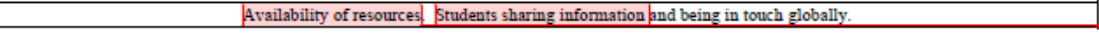 & Comment [M132]: New resources \\
\hline & & $\begin{array}{l}\text { Comment [M133]: Student-student } \\
\text { collaboration }\end{array}$ \\
\hline
\end{tabular}


Running head: TRANSFORMING TRADITIONAL CLASSROOMS INTO STUDENTCENTERED $21^{\text {ST }}$ CENTURY CLASSROOMS

\begin{tabular}{|c|c|c|}
\hline Submitter ID & What obstacles do you see to full implementation of 1:1 computing? & \\
\hline 1 & $\begin{array}{l}\text { I am worried that student will try to get out of showing work more in math if they do everything on the computer. I am a believer in paper and } \\
\text { pencil work for students to check for understanding. I also believe pote taking is a very important part of success in college and I fear that too } \\
\text { much computer useage may detract from that. }\end{array}$ & Comment [M134]: Note-taking \\
\hline 2 & |Trying to fit it into the curriculum and having it supplement not replace any of the CSOS| & Comment [M135]: Increased teacher workload \\
\hline$\frac{3}{4}$ & $\begin{array}{l}\text { Cooperation in sharing our resources and ability to use the technology effectively as quickly as possible. } \\
\text { How will students be responsible for a laptop? }\end{array}$ & $\begin{array}{l}\text { Comment [M136]: Teacher-teacher } \\
\text { collaboration }\end{array}$ \\
\hline 5 & $\begin{array}{l}\text { The obstacles can be how are the laptops going to be monitored during the class time to make sure all the students are on task and not searching } \\
\text { the web or chatting with eah other over the laptops. Also in a mathematics class it could be hard for some students to visually see like the } \\
\text { others. }\end{array}$ & $\begin{array}{l}\text { Comment [M137]: Student responsibility } \\
\text { Comment [M138]: Student responsibility }\end{array}$ \\
\hline 6 & Monitoring student behavior and website usage is a concem that I have; especially if programs like AB tutor on not available on the laptops. & Comment [M139]: Student responsibility \\
\hline \multirow{2}{*}{7} & $\begin{array}{l}\text { Just knowing what is out there to do } \\
\text { Fll need ideas and training playtime to work with the programs| }\end{array}$ & Comment [M140]: New resources \\
\hline & $\begin{array}{l}\text { I like to be prepared and I will not be able to teach and stay sane if I don't know what I am doing or if I worry about a method or activity all } \\
\text { night. }\end{array}$ & \\
\hline 8 & $\begin{array}{l}\text { I worry about students at the middle school level being able to take care of a laptopl especially if computers are going to be sent home. I think } \\
\text { with anything new, we will find more obstacles as we start this journey. }\end{array}$ & Comment [M141]: Student responsibility \\
\hline 9 & Lack of Internet access for some students at home & Comment [M142]: Inequity \\
\hline \multirow[b]{2}{*}{11} & $\begin{array}{l}\text { All must be committed to learning and experimenting } \\
\text { Obstacles... }\end{array}$ & Comment [M143]: Teacher buy-in \\
\hline & $\begin{array}{l}\text { Access at home when students want to continue there learning at home. There are more students without acces than most would like to believe. } \\
\text { Teachers themselves will become an obstacle in cases of those who will not be willing to "let go" of some of the control in their own classroom } \\
\text { Teachers will ahve to be come much more open to change and learning and this will be difficult for somel }\end{array}$ & Comment [M145]: Teacher buy-in \\
\hline 12 & $\begin{array}{c}\text { I will address math only. } \\
\text { Hardware- laptops connected to whiteboare } \\
\text { or multiple mobile presenters } \\
\text { Software - something better than equation } \\
\text { editor or the ability to } \\
\text { "write" directly on the laptop }\end{array}$ & Comment [M146]: New resources \\
\hline 13 & Time is my main concern, & Comment [M147]: Time \\
\hline $\begin{array}{ll}14 \\
15\end{array}$ & $\begin{array}{l}\text { Space, electricity, classroom size (numbers of students) etc. More physical in nature] } \\
\text { its availability to everyone and all classrooms] }\end{array}$ & $\begin{array}{l}\text { Comment [M148]: Logitical concermz/physical } \\
\text { space }\end{array}$ \\
\hline 16 & $\begin{array}{l}\text { I can see freachers not embracing the implemenation to its fullest extent. Some teachers may use the computers but are still teaching, just from } \\
\text { the online book. I can see where it would be hard to create meaningful lessons everyday that use the computers. I can also see people being } \\
\text { frustrated with students still acting the same way. }\end{array}$ & $\begin{array}{l}\text { Comment [M149]: Inequity } \\
\text { Comment [M150]: Teacher buy-in }\end{array}$ \\
\hline 17 & $\begin{array}{l}\text { I see special education students having a tough time traveling with laptops (if that happens) and femembering to save information daily lo } \\
\text { nothing gets "lost." }\end{array}$ & Comment [M151]: Student responsibility \\
\hline 18 & $\begin{array}{l}\text { I think that an obstacle will be to overcome fear. I also think that taking on too much too fast can be derrimental. } \\
\text { SSPACE FOR COMPUTER STORAGE. } \\
\text { SERVER BAND WITH NNSUFFICIENT. }\end{array}$ & \\
\hline \multirow{4}{*}{20} & $\begin{array}{l}\text { QUICKLY OUTDATED SOFTWARE BECOMING OBSOLETE. } \\
\text { Space, storage, safery, pesponsibility } \text { outlets for computers that are not fully charged????? }\end{array}$ & $\begin{array}{l}\text { Comment [M152]: Logistical concerms/physical } \\
\text { space }\end{array}$ \\
\hline & Laptop carrying cases would be allowed to transport equipment from class to class and school to home. & Comment [M153]: Student responsibility \\
\hline & Adequate plan time to restructure lessons that would be enhanced using the computers| & Comment [M155]: Time \\
\hline & Sharing links,sites etc... through a blog with other staff would belp introduce new ideaś & Comment [M156]: New resources \\
\hline \multirow{4}{*}{21} & \multirow{3}{*}{$\begin{array}{l}\text { Time and ability to montior what students are doing on the computers. } \\
\text { Trime to redesign our lessons, add information and lessons to the server, as well as time for task such open individual folders for grading }\end{array}$} & Comment [M157]: Time \\
\hline & & Comment [M158]: Student responsibility \\
\hline & & Comment [M159]: Planning \\
\hline & Dealing with technical problems. & Comment [M160]: Technical difficulties \\
\hline
\end{tabular}


CENTERED $21^{\text {ST }}$ CENTURY CLASSROOMS

\section{Appendix C: Sample from Staff Interviews}

Staff interviews were completed in the spring of 2011 and the spring of 2012. Interviews were recorded and saved digitally. Interviews were transcribed from the recordings and transcripts were saved by alias and date. The transcripts were analyzed for recurring themes. Such themes were noted using Microsoft's comment feature and tallied for frequency.

The sample below is the transcription from one full interview conducted in the spring of 2012. All names mentioned in the recording have been replaced with an alias. 


\section{CENTERED $21^{\mathrm{ST}}$ CENTURY CLASSROOMS}

Interview Transcription: Ms. Patel, $6^{\text {th }}$ Grade Social Studies and English

Spring 2012

What changes did you make to your content delivery when you changed to a one-to-one computing environment?

Much less use of text, much more use of, of course, the technology. And the ease at which you could get it, just walk across the room and everybody gets a laptop, enabled me to use that in all kinds of activities. I started rethinking. "How am I going to present this? How am I going to teach that?" and thinking "How am I going to use the laptops for this? How can I use laptops for that?" It just kinda changed a whole way of thinking about it. And kids were more motivated because it was not, even if it was the same material, it wasn 't paper/pencil, it wasn't in a book, it was on a laptop.

So you said you were looking for ways to present the material, do you feel that still did a lot of the presentation of the content or did that change as well?

I probably did less but I still included my presentation. Sometimes $I$ used it as a reinforcer afterwards to maybe peteach what I had gone over or as an introduction or even as a plain old "let's spark their interest" by tossing that out to them.

Comment [M67]: Reteach

Comment [M68]: Student-student collaboration

Comment [M69]: Procedures

Comment [M70]: Noise level

Comment [M71]: Grading practices Cominent [M72]: Use of uMs especially at the end of the year, used more of the Edline interactive quizzes, kinds of things. Homework hand-ins, automatically were connected into the gradebook. That had changed quite a bit. I had never done that before, and I want to do more of that next year.

What topics that were covered by professional development were helpful in facilitating one-to-one?

The most helpful thing, I think, was from Mrs. Scott and Mrs. Cooper because they had gotten their feet wet. They were the experimental guinea pigs. So when I was not sure how to do this or that, as far as every day handling of things, I would go to them "How do you do this? How do you do that?" So, talking with other teachers about how things worked, that helped a lot. Oh, that time we were up in Mrs. Todd's room, and we had a chance to just go through this plethora of sites. You know, look at this, look at that. That's what you need. You need time to experiment and plus somebody there as a guide. "Go here. Go there. Try this. Try that." That was very helpful and I used a lot of things that popped up there. You know, I thought, well, even if I don't know how to use that, I had a handle on it so that I could explore that a little bit more. That time to be able to explore is priceless. Time to explore in a group. Plus it was another one of those things where someone said "Try such and such site" or "So and so, I know you do a unit on this" or "You teach that, this is something you can use." Having other teachers in that room at the same time was real helpfiul.

What professional development topics do you feel you still need?

Maybe more of when the computer, when the laptop isn't functioning what kinds of troubleshooting things I can do before I have to call in the experts. I'm sure there are more things I can do. Even to have like a handout or a handbook of "When you see this, try this. When you see it doing this, try that." Because I just feel like, first of all, I feel guily because I'm constantly sending an email "Such and such isn't working" and then I find out it was a simple thing. You know, maybe something like that would be helpful, a little more of the technology troubleshooting. I think, especially the fact that they are always coming up with new sites, new things, new stuff, to periodically have that experience like we had, with everybody together. 'Let's explore some more. Let's find out what's out there " Because, I have a feeling that like every six months that's just unbelievably increased.

Comment [M77]: Technical difficulties

Did you have concerns when we started one-to-one computing? And if so, have they changed or do you still have concerns?

Before we started, my biggest concem.... had visualized a kid sitting in front of a laptop, totally closed off from the rest of the class and just going into it like 'cyber-mode.' And I thought that was not a good idea, but I thought "This is what's coming. This is what's going to happen." And I found that the opposite was true. There is more of the kids collaborating with each other because of the laptops, learning together, especially the range of ability levels in a social studies classroom, because we get 'em all, from the extremely genius down to the total other end, being able to work together to do a product and they work together and I am more on the sidelines. And then I kind thought, I think part of it, I was kinda concerned I would be replaced. No. I will not be replaced. And I wasn't replaced. I was just part of them, exploring and tying to figure things out together. I taught them, they taught me. It was very enriching.

Comment [M73]: Teacher-teacher collaboration (grade level)

Comment [M74]: New resources

Comment [M75]: Teacher-teacher collaboration (content area)

Comment [M76]: Teacher-teacher collaboration

Are there still any concerns?

I don't think so. Every time I think, like I'm thinking of next year's class, the class we just sent on, they were wonderful and I thought, "I hope that the ones coming up are as responsible, they follow the AUP, they do what they re supposed to do, as well as the class we just had." Because I don't want to spend my time, going around and monitoring "Are you on the correct site? Are you doing what you' re supposed to do? Are you going somewhere you' re not supposed to be? "You know, it was relaxing being able to trust those kids, knowing they're doing what they re supposed to do. And I hope that continues. So it's always that same kind of feeling you get every time a new class is coming up. So that would be it. 
CENTERED $21^{\text {ST }}$ CENTURY CLASSROOMS

\section{Appendix D: Sample from Classroom Observations}

Classroom observations were completed in the fall of 2010, the spring of 2011, the fall of 2011, and the spring of 2012. Field notes from formal observations were typed following the observation and saved by teacher alias and date. Aliases were used for all teachers on all field notes and typed notes. The typed observations were analyzed for recurring themes. Such themes were noted using Microsoft's comment feature and tallied for frequency.

The sample below is the typed observation from one formal observation of a full class period in the spring of 2011. 


\section{CENTERED $21^{\text {ST }}$ CENTURY CLASSROOMS}

Classroom Observation of Mrs. Archer

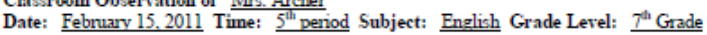

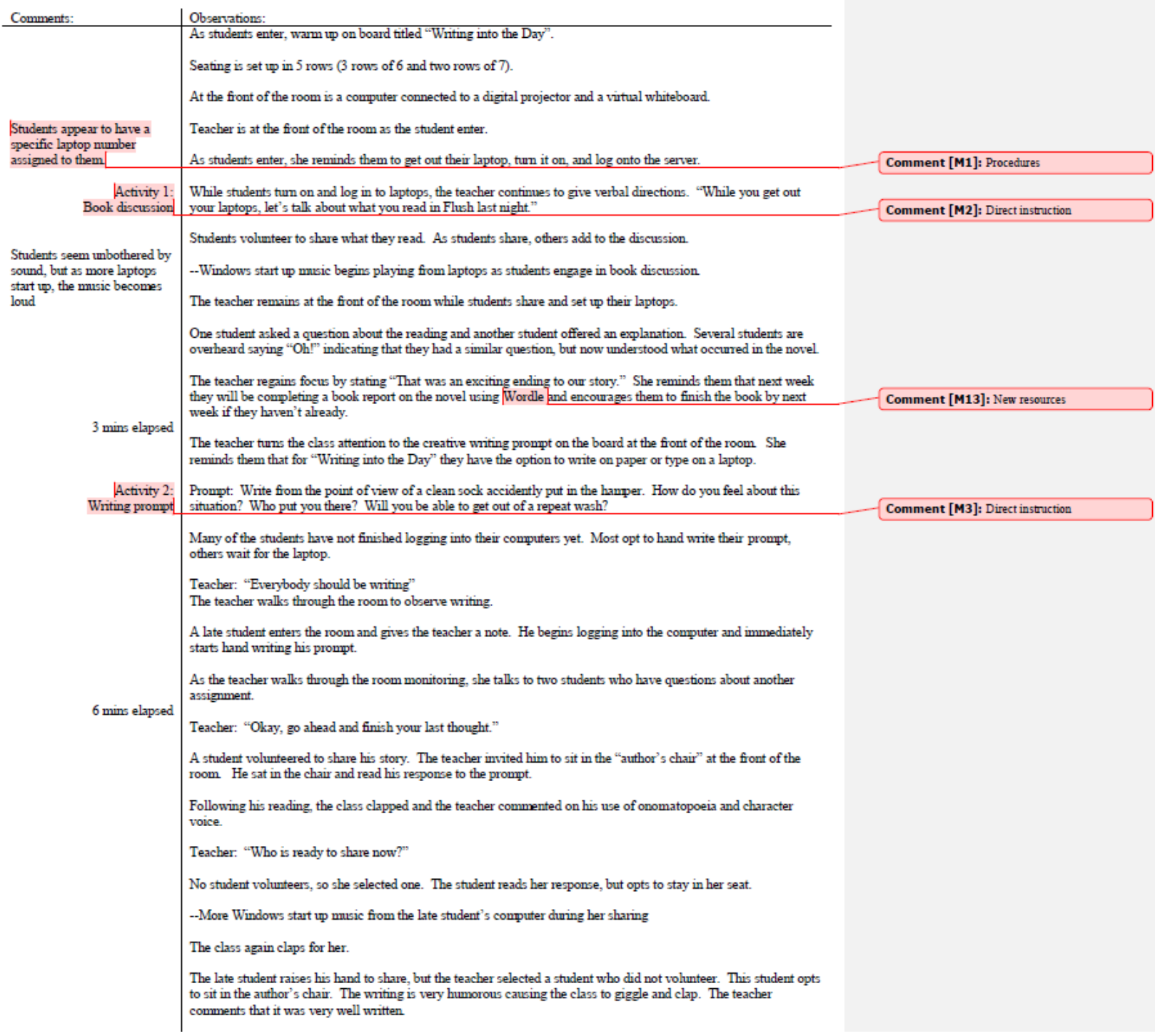



CENTERED $21^{\text {ST }}$ CENTURY CLASSROOMS

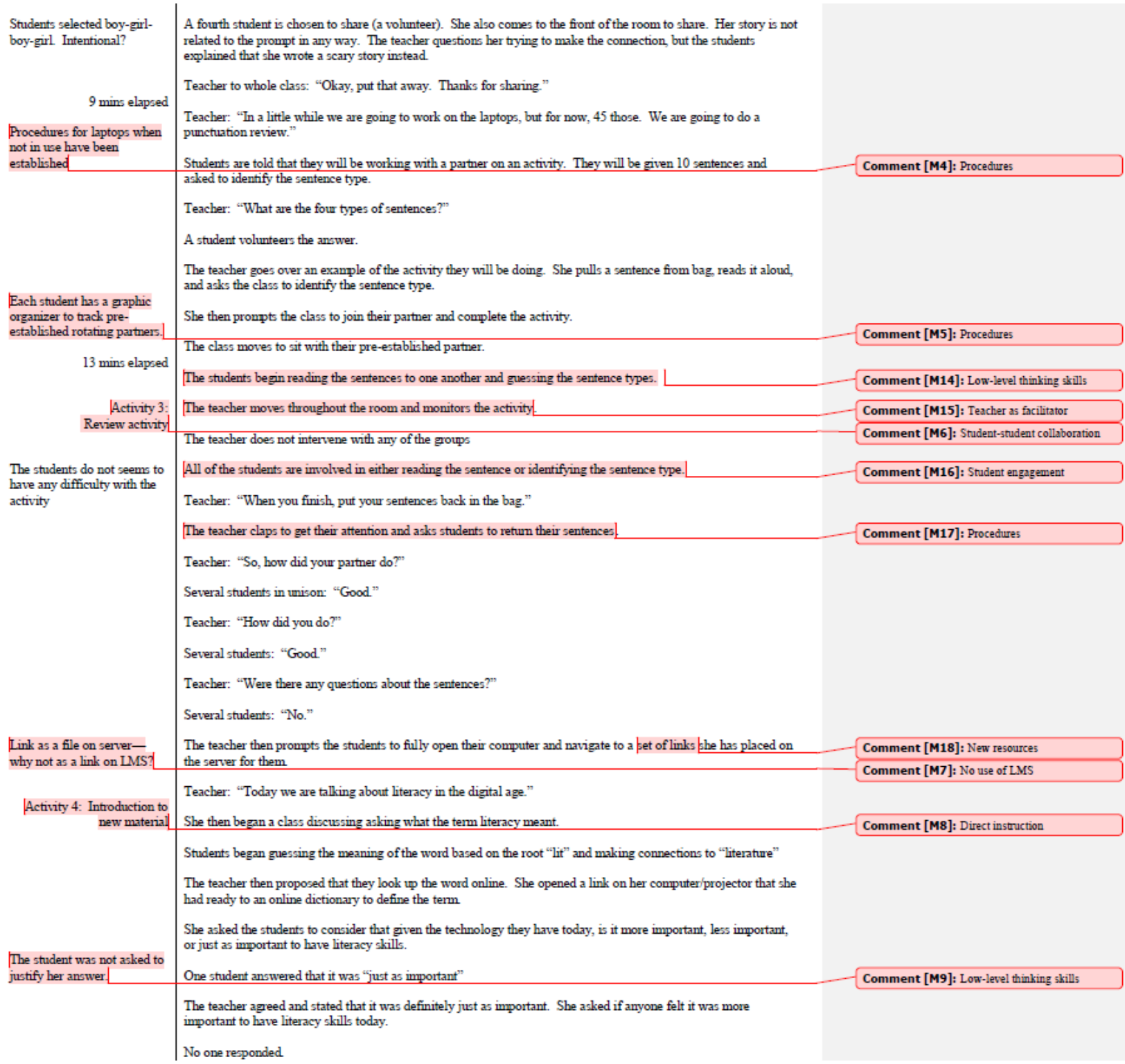




\section{CENTERED $21^{\text {ST }}$ CENTURY CLASSROOMS}

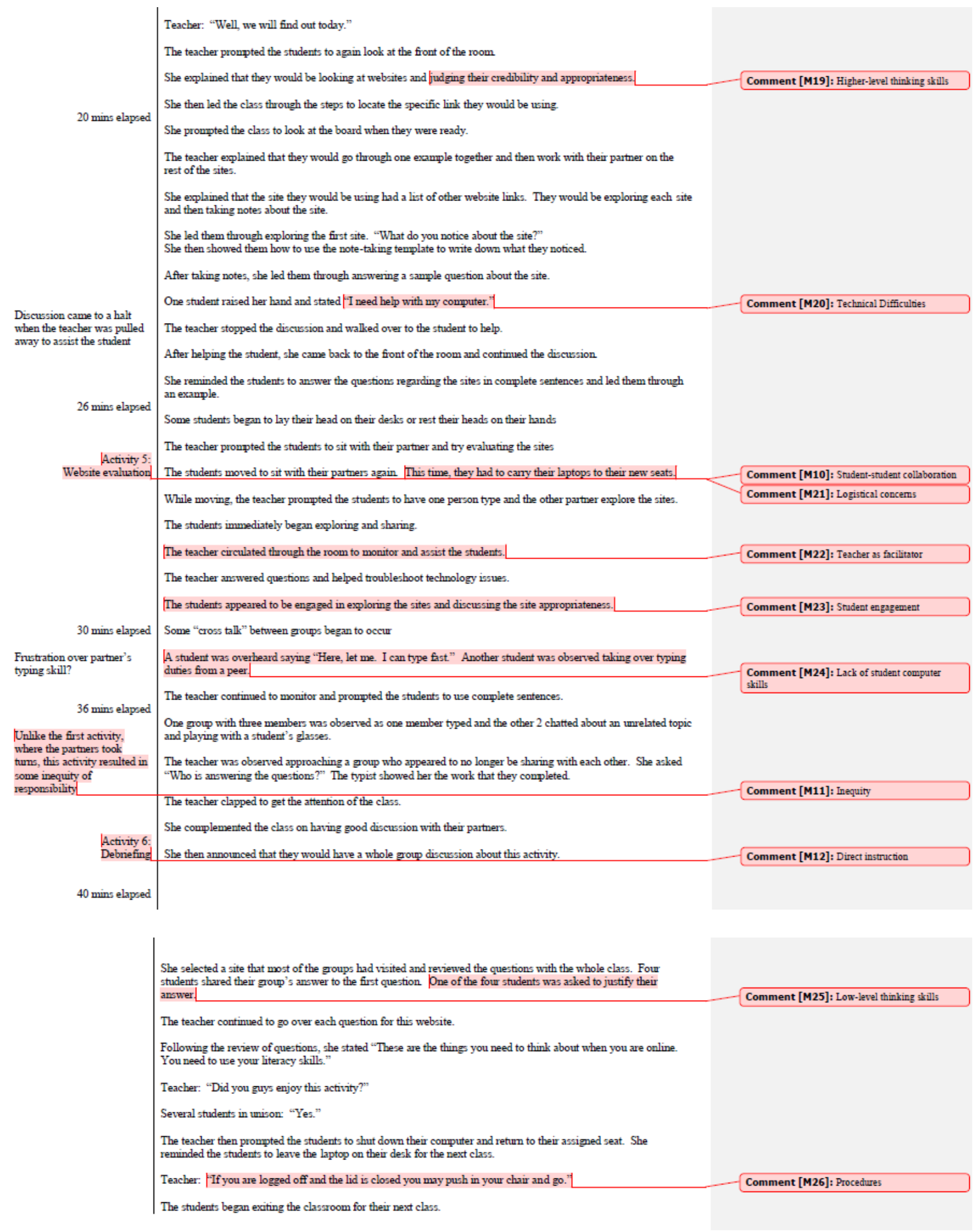




\section{CENTERED $21^{\text {ST }}$ CENTURY CLASSROOMS}

\section{Appendix E: Sample from Discussion Groups}

Discussion groups were held with the Implementation Team once per month to assist in determining school-wide needs and progress. Similar discussions were held with each gradelevel team during professional development sessions or as stand-alone meetings throughout all four semesters of the study. Pre-determined agendas provided the format of the meetings, and hand-written notes were added to the agendas. Following grade-level or Implementation team meetings, notes were typed onto the existing agenda and saved by date. Aliases were used for all teachers on typed notes. The typed notes were analyzed for recurring themes. Such themes were noted using Microsoft's comment feature and tallied for frequency.

The sample below includes the original agenda and the agenda with compiled notes from grade-level team discussions held on September 1, 2010. The purpose of the meeting was to review the findings of the initial needs assessment survey and begin planning the direction of professional development. 


\section{Planning with the Big Picture in Mind}

Grade-Level Team Agenda 9/1/10

- What is the "Big Picture"?

- A look at the survey results: where do we want to go?

- School-wide Goals:

- Personalizing student learning (taking charge of their own learning)

- Student centered v. teacher centered

- Project Based Learning (PBL)

- Blended learning/Edline interactive classroom

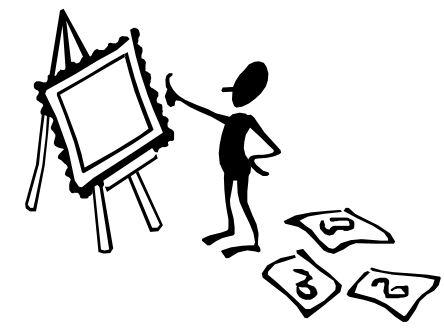

Overall Goals:

\begin{tabular}{|c|c|}
\hline Needs & \\
\hline Wants & \\
\hline
\end{tabular}

Professional Development Needs:

\begin{tabular}{|c|c|}
\hline $\begin{array}{l}\text { Teacher } \\
\text { concerns }\end{array}$ & \\
\hline $\begin{array}{l}\text { PD input from } \\
\text { teams }\end{array}$ & \\
\hline $\begin{array}{c}\text { Multi- } \\
\text { disciplinary } \\
\text { curricular } \\
\text { collaboration }\end{array}$ & \\
\hline
\end{tabular}




\section{Planning with the Big Picture in Mind}

Grade-Level Team Agenda 9/1/10

- What is the "Big Picture"?

- A look at the survey results: where do we want to go?

- School-wide Goals:

- Personalizing student learning (taking charge of their own learning)

- Student centered v. teacher centered

- Project Based Learning (PBL)

- Blended learning/Edline interactive classroom

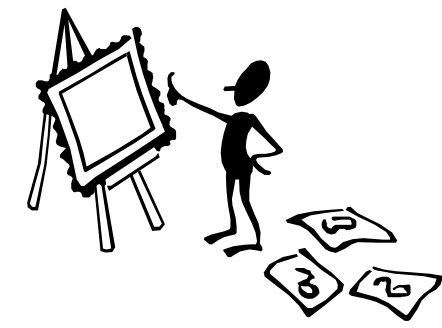

Overall Goals:

\begin{tabular}{|c|c|c|c|}
\hline & $6^{\text {th }}$ Grade & $7^{\text {th }}$ Grade & $8^{\text {th }}$ Grade \\
\hline Needs & $\begin{array}{l}\text { Project-based learning } \\
\text { environments } \\
\text { - Method to help track } \\
\text { SRs/ABCs } \\
\text { (computerized) }\end{array}$ & $\begin{array}{l}\text { - "I just need to see it in } \\
\text { action. I don't know } \\
\text { what to expect." } \\
\text { - Video of } 1: 1 \text { ? }\end{array}$ & $\begin{array}{l}\text { - Student contracts for } \\
\text { computer use } \\
\text { - } \quad \text { Revisit the AUP (reteach } \\
2^{\text {nd }} \text { semester) } \\
\text { - } \quad \text { Policy for repeat } \\
\text { offenders }\end{array}$ \\
\hline Wants & 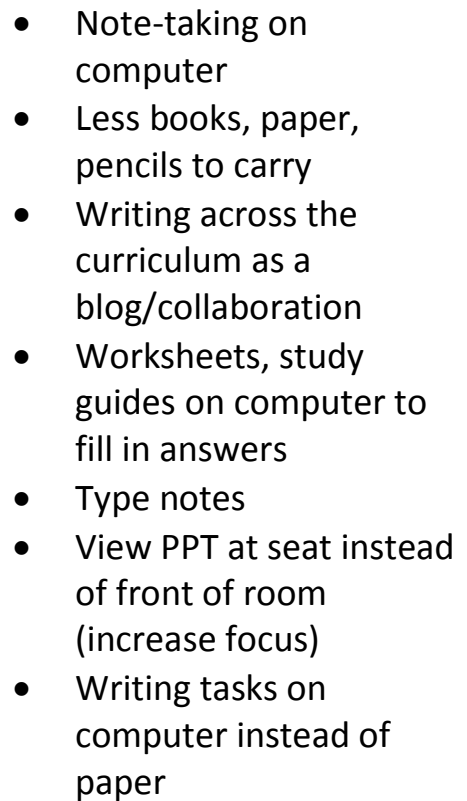 & - Unsure & $\begin{array}{l}\text { - } \quad \text { Tables for PBL } \\
\text { - } \text { Additional electrical } \\
\text { - } \text { Wantlets } \\
\text { - } \quad \text { Want to see group work } \\
\text { facilitator } \\
\text { - } \quad \text { Varied methods for } \\
\text { - } \text { student presentation } \\
\text { Easier method to type } \\
\text { math symbols (user- } \\
\text { friendly) }\end{array}$ \\
\hline
\end{tabular}


Running head: TRANSFORMING TRADITIONAL CLASSROOMS INTO STUDENTCENTERED $21^{\text {ST }}$ CENTURY CLASSROOMS

Professional Development Needs:

\begin{tabular}{|c|c|c|c|}
\hline & $6^{\text {th }}$ Grade & $7^{\text {th }}$ Grade & $8^{\text {th }}$ Grade \\
\hline $\begin{array}{l}\text { Teacher } \\
\text { concerns }\end{array}$ & $\begin{array}{l}\text { - "How long will it take } \\
\text { to change curriculum?" } \\
* * * \text { Don't change } \\
\text { curriculum, change } \\
\text { delivery** }\end{array}$ & $\begin{array}{l}\text { - Need to see PBL and } \\
1: 1 \text { computing }\end{array}$ & \\
\hline $\begin{array}{c}P D \text { input } \\
\text { from teams }\end{array}$ & - $\quad \mathrm{PBL}$ & $\begin{array}{l}\text { Videos or visiting } \\
\text { schools implementing } \\
\text { PBL or 1:1 computing }\end{array}$ & $\begin{array}{l}\text { - Webinars on how to } \\
\text { use tools } \\
\text { - Social networking for } \\
\text { students }\end{array}$ \\
\hline $\begin{array}{l}\text { Multi- } \\
\text { disciplinary } \\
\text { curricular } \\
\text { collaboration }\end{array}$ & & & $\begin{array}{l}\text { Vertical PD based on } \\
\text { content } \\
\text { Time and PD for } \\
\text { collaborating on } \\
\text { projects } \\
\text { Webcams to } \\
\text { collaborate from class } \\
\text { to class }\end{array}$ \\
\hline
\end{tabular}




\section{Sample F: Sample from Collected Artifacts}

Various artifacts were collected over the course of the four semesters studied. Most of the artifact collected were digital in nature and could be saved by artifact type, date, and if applicable, teacher name. All artifacts were analyzed for purpose and were code based on theme. For digital documents, such themes were noted using Microsoft's comment feature and tallied for frequency. Documents existing in hard-copy only were described in a Microsoft Word log and coded for theme.

The sample below is a series of screenshots from the school's learner management system. Screenshots were collected from all core classes during the spring of 2011 and the spring of 2012. The screenshots below came from the eighth grade science classroom. All text indicating the name of the school, teacher, or class code has been redacted. The first image is the class homepage, followed by the list of documents and applications from the "Assignments" folder, and finally a list of the items found within one unit of study. 

CENTERED $21^{\text {ST }}$ CENTURY CLASSROOMS
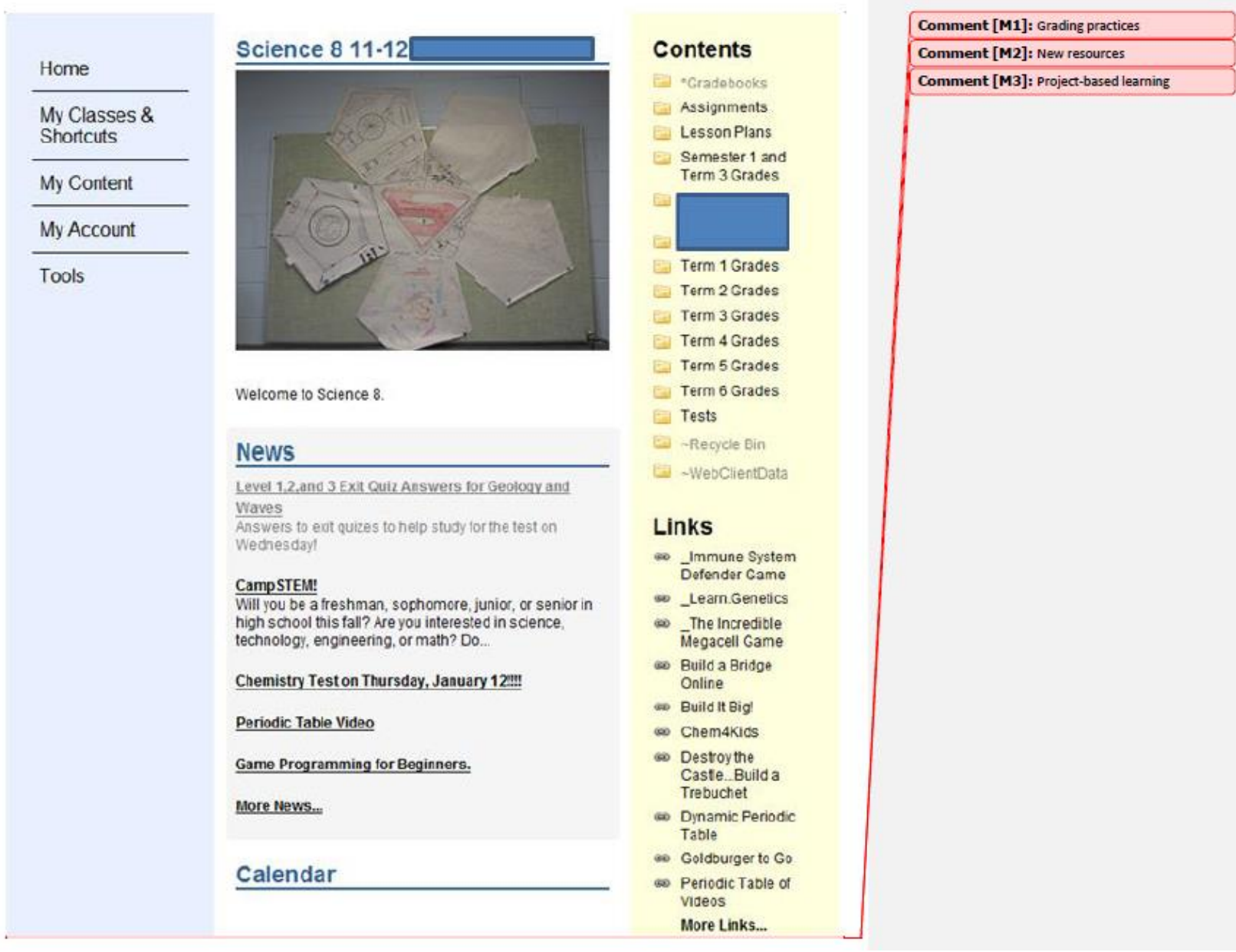

\begin{tabular}{l} 
Home \\
\hline $\begin{array}{l}\text { My Classes \& } \\
\text { Shortcuts }\end{array}$ \\
\hline My Content \\
\hline My Account \\
\hline Tools
\end{tabular}

\section{Assignments}

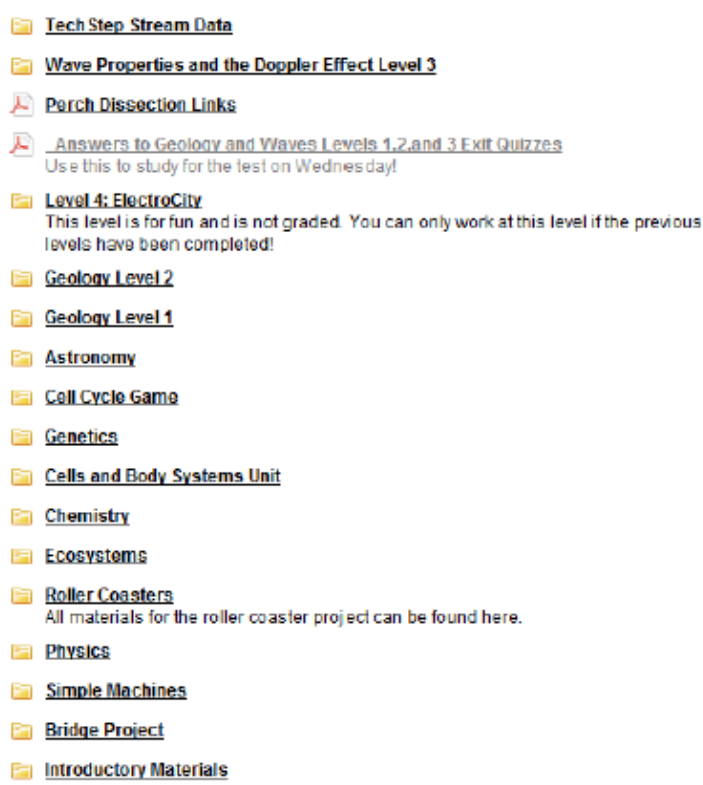

E] Introductory Materials 

CENTERED $21^{\text {ST }}$ CENTURY CLASSROOMS

\begin{tabular}{l} 
Home \\
\hline My Classes \& \\
\hline My Content \\
\hline My Account \\
\hline Tools \\
\hline
\end{tabular}

\section{Cells and Body Systems Unit}

1. Rules of the Game 01/16/12 Mon - 02/10/12 Fri Cells and Body Systems the Chutes and Ladders Way!

D. Level 1 and 2 Exit Ticket Answer Key

$\exists$ Lovel 1 Hand-In Turn in any digital producls for Level 1 here!

1. Level 1 of the Game 01/16/12 Mon - 02/10/12 Fri

(1) Level 2Bodv Svstems Extra!!I

. Hand in any digital products for Level 2 here

A. Level 2 of the Game

01/23/12 Mon - 01/25/12 Thu

Level 3 Hand-in

Hand in any digital products for Level 3 here

(1) Level 3 of the Game 01/27/42 Fri - 02/01/12 Wed

$1-$ Pre-Test and Answer Key

1. Presontation Rubric 02002/12 Thu - 02:06/12 Mon
Comment [M5]: Blended learning Comment [M6]: Differentiation Comment [M7]: Student as researche 